\title{
Journey of Profound Life Lessons, Learning, Change and Self-awareness: Preparation for a Role Transition from a Senior Saudi Registered Nurse to a Specialist Palliative Care Nurse
}

\section{Fatimah Alabduljabbar*}

Senior Nurse Specialist. MSc Palliative, Oncology and Aged Care at Johns Hopkins Aramco Healthcare (JHAH), Saudi Arabia

*Corresponding Author: Fatimah Alabduljabbar, Senior Nurse Specialist. MSc Palliative, Oncology and Aged Care at Johns Hopkins Aramco Healthcare (JHAH), Saudi Arabia.
Received: August 15, 2020

Published: October 28, 2020

(C) All rights are reserved by Fatimah

Alabduljabbar.

\begin{abstract}
Background: A transition journey took me as a Saudi Senior Registered Nurse (SRN), and a woman seeking continuous challenges and improvements, overseas to prepare for a Specialist Palliative Care Nurse role (SPCN). This is also due to the lack of opportunities in my country. This paper describes my preparation, sheds some light from transition theories, including the transition challenges involved in general and more specifically to my case. More importantly, the learning and blessings gained throughout the process.

Methods: Owing to the nature of the transition process, I use complex mixture of methods. Through auto-ethnography self-reflection, I deliberately make myself vulnerable as I attempt to provide a clear analysis of the diverse experiences of a transitioning SRN to a SPCN role. My literature review draws from a wide range of sources, disciplines and compares these to my experiences. Additionally, I use different tools and means to gain more understanding.

Results: Challenges of transitioning to SPCN include role ambiguity, the need to fill the educational gap, and adapting to a new culture. Benefits include increased space to pursue my passion and ability to make a positive impact as well as self-awareness and change.

Conclusion: True improvements in quality of healthcare needs to be more inclusive and consider smooth transition of RNs to SPCNs. The Saudi government and stakeholders are encouraged to provide more opportunities for nurses to fulfill the increasing demands. Nurses are encouraged to seek opportunities to improve life.

Keywords: SRN; SPCN; Clinical Nurse Specialist (CNS); Advance Nursing Practice; Hospital; Role Transition; Leadership; Teamwork; Communication; Referrals; Culture and Paternalism; Skills; Challenges; Reflection; Auto-ethnography
\end{abstract}

\section{Introduction}

Role transition from a RN to an advanced practice nurse (APRN) or specialist nurse (SN) is not free of challenges [67]. Most planned changes allow learning time for us to close the gap as we enter different roles at different levels of readiness [4]. However, some changes are beyond our control, thus, adaptation is required.

In order to prepare for a specialist role, competent nurses need "the expert knowledge base, complex decision-making skills and clinical competencies for expanded practice based on the context and/or country one is credentialed to practice" [33]. In addition, one should have essential characteristics (e.g. passion, commitment, dedication, empathy and others) [9].
There is an increasing need for well educationally prepared, confident, competent and expert SPCNs, who are APRNs in acute care settings [57] to provide high quality, culturally sensitive, holistic palliative and end of life (EOL) care and to train the generalist health professionals (HP) [48]. They must also be ready to handle the ageing population [48] and those with life-limiting illnesses [29]. Further, they are needed to tackle the culturally diverse population in Saudi hospitals [21].

Literature on CNS has been accumulated for over nine decades [27]. Developed countries like the USA and UK had established CNS by 1970s [5]. Studies have proved the benefits of such role $[12,35,34,40,43,55,57,75]$, and it has been recommended by the 
World Health Organization (WHO). Nonetheless, it is lacks from both academic curricula and health culture in Saudi Arabia (SA) $[31,39]$ in addition to limited data on transition from RN to SPCN.

Given these gaps and considering the increasing opportunities available globally for nurses to develop and grow professionally as SNs, [30,39], and in an attempt to be a "critical being" [8], this practicum paper presents my preparation journey as an experienced Saudi SRN transitioning to a SPCN in Australia. It critically investigates and critiques the literature on role transition and the roles of the SPCN in hospital settings and challenges involved. Through an integration of multiple lenses, tools and methods, it sheds light on my own case and presents my skills and development path.

While different titles (APN, CNS, CNC, NP "nurse practitioner") are in use interchangeably worldwide, for the purpose of clarity, I use the term (SPCN) throughout this paper and draw from the literature involving all of those, as they are all specialist nurses and APRNs with almost same main roles, challenges and skills.

\section{Methods}

\section{Paper design and rational}

This paper is inspired by the famous novel "Alice in wonder land" [44] and 'the love of mystery'. The way it is done embraces the phrase "curiouser and curiouser" from this tale, which becomes popular in English lexicon, alluding to a journey of a complex mix of miracles and adversities, where only the 'divine rules' apply.

I "think laterally" [36], read and draw from different disciplines and specialties. I also shed light using several theoretical lenses (e.g. transition theory) [1] and the Middle Range transition theory [49] and self-in-relation theory [50]) on my transition journey and my preparation to a SPCN role to provide different angles of the phenomenon [16].

Studying the area of role transition to SPCN require acknowledging its complexity beyond the theoretical best available evidence. Hence, I endeavor to craft a mixture of theoretical knowledge through the literature review, while comparing it to what I found in the real life, as I draw on my 'real life experiences' as a carrier of two luggage of cultures and ways of 'being' i.e. a postgraduate student and a SRN, during my transition and clinical placement in Melbourne. Confirmation of work placement form is in appendix 1.

"Art serves as a means to convey life" [15]. As a humble artist, I use the powerful, transformative, form of self-reflection and writing, 'Auto-ethnography' and position it in the researched cultures/ hospital environments [15]. This self-reflection has been proved to enhance clinically effective patient-centered practice and quality of care $[13,76]$.
Writing auto-ethnography requires and is a test of our ability to be 'self-vulnerable' [15]. It is a 'messy job' that requires open, honest searching inward ones' self, trust, and 'conscious mind'. As it changes our perception of time [15], it helped me evaluate my past, balance my presence and plan for the future leading to transformation.

The amount of literature available $[32,46,60]$ on the therapeutic benefits of auto ethnography is increasing. I hope through my writings to touch people in ways that enable them to think consciously and be courageous to look deep inward and learn from their experiences as well as mine, as this stimulates creativity and innovation. For example, as I recall reading and watching "Alice in wonderland" by Lewis Carroll, 1865 [44] again as an adult, I can assure the therapeutic benefits of doing so consciously with critical mind. While it made me ponder about my life, it allowed growth and healing to occur through learning multiple life lessons.

In addition to these approaches, I am being proactive by using tools like the VIA survey which is "a psychometrically validated personality test that measures an individual's character strengths [72]. The aim of this is to gain 'self-awareness' which is an "innate psychological function" [38], which facilitates the practice of "Exquisite empathy" and is beneficial for SPCNs when giving families and patients emotional support [65]. Moreover, as leadership is an important role of the SPCNs to enhance the patient/family care [68], I use " The Leadership Behavior Matrix" (LBM) in exploring my leadership style and roles. What make this work different, creative, and innovative while addressing the gaps in the literatures are the humble messiness and the open, proactive approach in attempting to profile myself.

To create something new, one needs more than intellect. It comes from instinct acting out of inner necessity. The creative mind reaches out to the objects it loves. Despite its hardships, this searching journey provided many blissful moments and I continued to follow my heart into a process of transformation and change. As Tim Harford [74] highlighted, "we need to gain a bit more appreciation for the unexpected advantages of having to cope with a little mess".

\section{Literature search strategy}

The following databases were searched: Google scholar, PubMed, CINHAL and Scopus. The references lists of each article were also manually searched. Table 1 provides a summary of the articles using different key terms. Other publications' searches were conducted to obtain further information pertaining to the SPCN such as the National Association of CNS and The Saudi Commission for Health Specialties or just to provide support by drawing from different online blogs (e.g. writing for research, Quiet Revolution). 
Table 1: Summary of the Articles.

\begin{tabular}{|c|c|c|c|c|c|}
\hline Paper & $\begin{array}{c}\text { Country of } \\
\text { Origin }\end{array}$ & Sample Used & $\begin{array}{l}\text { Research } \\
\text { Design }\end{array}$ & Aim & Summary of Key findings \\
\hline $\begin{array}{l}\text { (Anderson, } \\
\text { 2009) }\end{array}$ & USA & $\begin{array}{l}18 \text { CNSs and NPs } \\
\text { in their first or } \\
\text { second year of } \\
\text { full-time teach- } \\
\text { ing in accredited, } \\
\text { baccalaureate } \\
\text { programs in the } \\
\text { Upper Midwest. }\end{array}$ & $\begin{array}{c}\text { Descriptive and } \\
\text { explanatory } \\
\text { study } \\
\text { Semi structured } \\
\text { interview }\end{array}$ & $\begin{array}{l}\text { To explain and de- } \\
\text { scribe the work-role } \\
\text { transition of clinical } \\
\text { experts to the nurse } \\
\text { educators in a bacca- } \\
\text { laureate program. }\end{array}$ & $\begin{array}{l}\text { The study validated work-role transi- } \\
\text { tion attributes of (a) dynamic and } \\
\text { developmental, (b) emotional work, (c) } \\
\text { critical tasks, and (d) diffusion through } \\
\text { role boundaries. } \\
6 \text { patterns describing phases of the } \\
\text { work-role transition from clinical ex- } \\
\text { pert to novice nurse educator in a bac- } \\
\text { calaureate program. a pre-transition } \\
\text { phase, four working phases-easing } \\
\text { into transition, early transition, middle } \\
\text { transition, and later transition-and a } \\
\text { final pattern of throughout the transi- } \\
\text { tion. } \\
\text { It explored the learning techniques, } \\
\text { which promote the understanding of } \\
\text { core competencies and to enhance the } \\
\text { role transition. } \\
\text { It is recommended for participants } \\
\text { to get the orientation practice, which } \\
\text { facilitate the work role transformation. }\end{array}$ \\
\hline $\begin{array}{c}\text { (Becker., et al. } \\
\text { 2012) }\end{array}$ & UK & $\begin{array}{c}\text { 10-15 Staff } \\
\text { Nurses }\end{array}$ & Qualitative & $\begin{array}{l}\text { To portray the struc- } \\
\text { ture, procedure, and } \\
\text { results of a power- } \\
\text { ful Clinical practice } \\
\text { council (CPC) where } \\
\text { CNSs effectively draw } \\
\text { in bleeding edge clini- } \\
\text { cians in advancing } \\
\text { nursing mind that is } \\
\text { confirmation based. } \\
\text { Clinical medical } \\
\text { caretaker author- } \\
\text { ity administration is } \\
\text { progressively made } \\
\text { noticeable as CNSs } \\
\text { successfully include } \\
\text { staff attendants } \\
\text { practically speaking } \\
\text { changes to enhance } \\
\text { persistent results. }\end{array}$ & $\begin{array}{l}\text { Enhancing staff medical caretakers' } \\
\text { demonstrable skill through expanded } \\
\text { utilization of initiative practices, self- } \\
\text { sufficient practice, and the capacity } \\
\text { to impact patients' results decidedly } \\
\text { using proof based standards can be ac- } \\
\text { complished by furnishing cutting edge } \\
\text { clinicians with a system to accomplish } \\
\text { these results. } \\
\text { Achievement of the CPC relies on upon } \\
\text { the CNSs' authority and responsibility } \\
\text { in tutoring staff medical attendants } \\
\text { during the time spent creating EBP } \\
\text { reports. } \\
\text { The CPC gives a structure and instru- } \\
\text { ment through which staff medical } \\
\text { caretakers can take part and contribute } \\
\text { their clinical aptitude, a key segment } \\
\text { of EBP, to nursing records, grow their } \\
\text { part as pioneers, and utilize the most } \\
\text { recent confirmation to accomplish the } \\
\text { best results for patients. }\end{array}$ \\
\hline
\end{tabular}




\begin{tabular}{|c|c|c|c|c|c|}
\hline $\begin{array}{c}\text { (Booth, S, } \\
\text { Edmonds, } \mathrm{P} \\
\text { and Kendall, } \mathrm{M} \\
\text { 2009) }\end{array}$ & UK & $\begin{array}{l}\text { Palliative nurses } \\
\text { in several set- } \\
\text { tings in different } \\
\text { case studies }\end{array}$ & Qualitative & $\begin{array}{c}\text { To demonstrate the } \\
\text { key values that pallia- } \\
\text { tive nurses must have } \\
\text { in a clinical environ- } \\
\text { ment } \\
\text { To demonstrate the } \\
\text { roles that palliative } \\
\text { nurses are involved } \\
\text { in when working in a } \\
\text { clinical setting }\end{array}$ & $\begin{array}{l}\text { Palliative nurses within the hospital } \\
\text { setting work in a supportive and advi- } \\
\text { sory role. As such, they always work in } \\
\text { teams and being successful needs them } \\
\text { to invest time in understanding team } \\
\text { members } \\
\text { Palliative nurses must be flexible in ap- } \\
\text { plication of their knowledge in order to } \\
\text { be successful and even accommodate } \\
\text { their fellow team members } \\
\text { Transitioning to the new role takes } \\
\text { time. While fresh graduates feel } \\
\text { confident to even open consultancies, } \\
\text { they need the experience of working in } \\
\text { an acute hospital setting before doing } \\
\text { these duties on their own. }\end{array}$ \\
\hline $\begin{array}{l}\text { (Brennan and } \\
\text { Mcsherry, } \\
\text { 2007) }\end{array}$ & UK & $\begin{array}{l}14 \text { students } \\
\text { with previous } \\
\text { experience as } \\
\text { a Health care } \\
\text { assistant (HCA) } \\
\text { within the field } \\
\text { of adult nursing. } \\
\text { (At least } 6 \text { month } \\
\text { experienced par- } \\
\text { ticipants of adult } \\
\text { field as a HCA as } \\
\text { compare to less } \\
\text { than } 6 \text { months } \\
\text { experience). }\end{array}$ & $\begin{array}{l}\text { Qualitative } \\
\text { Research, } \\
\text { Descriptive } \\
\text { study over } 8 \\
\text { months, } \\
\text { Empirical } \\
\text { research } \\
4 \text { focus groups, } \\
\text { Thematic con- } \\
\text { tent analysis }\end{array}$ & $\begin{array}{c}\text { To determine the pro- } \\
\text { cesses of transition } \\
\text { from HCA to student } \\
\text { Nurse. } \\
\text { To investigate how } \\
\text { transition influence } \\
\text { the students' knowl- } \\
\text { edge. } \\
\text { To identify the experi- } \\
\text { ence of student per- } \\
\text { ception of transition } \\
\text { from HCA to student } \\
\text { nurse. }\end{array}$ & $\begin{array}{l}\text { Clinical issues and culture shock both } \\
\text { found in positive and negative percep- } \\
\text { tions in this process. } \\
\text { The concept of "comfort zone" is intro- } \\
\text { duced from this study, which explored } \\
\text { the purposeful reversal into HCA role } \\
\text { by the participants. } \\
\text { A framework for the transition and } \\
\text { professional socialization from HCA to } \\
\text { student nurse is provided. } \\
\text { This study will help in identifying, } \\
\text { addressing, and aiding, socialization } \\
\text { needs into their new role as student } \\
\text { nurse. }\end{array}$ \\
\hline $\begin{array}{c}\text { (Brinkert, R } \\
\text { 2010) }\end{array}$ & USA & - & $\begin{array}{l}\text { Literature } \\
\text { review }\end{array}$ & $\begin{array}{l}\text { To determine the } \\
\text { causes of conflict } \\
\text { among nurses } \\
\text { To determine the ben- } \\
\text { efits of communica- } \\
\text { tion in resolving nurse } \\
\text { conflicts }\end{array}$ & $\begin{array}{l}\text { One of the causes of conflicts nurses is } \\
\text { lack of clear role description. However, } \\
\text { this can be avoided by ensuring that } \\
\text { nurses have enhanced communication } \\
\text { skills. Conflicts are bound to occur } \\
\text { especially considering inadequacy of } \\
\text { resources and burnout due to long } \\
\text { working hours. }\end{array}$ \\
\hline $\begin{array}{l}\text { (Carryer, Gard- } \\
\text { ner, Dunn, and } \\
\text { Gardner, 2006) }\end{array}$ & $\begin{array}{c}\text { Australia } \\
\text { and New } \\
\text { Zealand }\end{array}$ & $\begin{array}{l}15 \text { nurse prac- } \\
\text { titioners of } 2 \\
\text { countries. }\end{array}$ & $\begin{array}{l}\text { Interpretive } \\
\text { study }\end{array}$ & $\begin{array}{l}\text { Objective of this } \\
\text { study is to explain the } \\
\text { role of NPs in New } \\
\text { Zealand and Australia, } \\
\text { which developed the } \\
\text { national parameters } \\
\text { identification, and } \\
\text { education of NPs. } \\
\text { To investigate the cur- } \\
\text { rent standards of edu- } \\
\text { cation and command- } \\
\text { ment of requirements } \\
\text { for the NP a processes } \\
\text { in Australia and New } \\
\text { Zealand }\end{array}$ & $\begin{array}{l}\text { It is found by this study to substanti- } \\
\text { ate the role of NPs to characterize into } \\
\text { three areas: high powered practice, } \\
\text { Clinical leadership, professional effi- } \\
\text { cacy as well as the learning techniques } \\
\text { which promote the understanding of } \\
\text { core competencies and to enhance the } \\
\text { role of unification among the students. }\end{array}$ \\
\hline
\end{tabular}




\begin{tabular}{|c|c|c|c|c|c|}
\hline $\begin{array}{l}\text { (Chick, Sievers, } \\
\text { Negley, and } \\
\text { Tammel, 2012) }\end{array}$ & & $\begin{array}{c}45 \% \text { survey, } 6 \% \\
\text { of nursing } \\
\text { staff(disease } \\
\text { specific educa- } \\
\text { tional domain), } \\
21 \% \text { of nursing } \\
\text { staff, } \\
\text { Relationship } \\
\text { based caring } \\
\text { model used. }\end{array}$ & $\begin{array}{l}\text { Descriptive } \\
\text { study }\end{array}$ & $\begin{array}{l}\text { To investigate the } \\
\text { disease specific edu- } \\
\text { cation plans, obstacles } \\
\text { while using the dis- } \\
\text { ease specific patient, } \\
\text { how much education } \\
\text { ion regarding cancer } \\
\text { patients is important } \\
\text { for nurses. } \\
\text { To implement the web } \\
\text { based learning for } \\
\text { students. }\end{array}$ & $\begin{array}{l}\text { It is revealed that to organize the strat- } \\
\text { egies to implement the CNSs project } \\
\text { in a consistent and structured way } \\
\text { for medical nurses to exploit the best } \\
\text { disease specific education resources. In } \\
\text { this way Students will be aware of the } \\
\text { patients need and care. }\end{array}$ \\
\hline $\begin{array}{l}\text { (CLARK., et al. } \\
\text { 2015) }\end{array}$ & UK & $\begin{array}{l}10 \text { nurses } \\
\text { recorded their } \\
\text { responses on } \\
\text { designed ques- } \\
\text { tioners }\end{array}$ & $\begin{array}{l}\text { Pilot study was } \\
\text { carried out }\end{array}$ & $\begin{array}{l}\text { To evaluate the impact } \\
\text { of training for devel- } \\
\text { opment of skill to be } \\
\text { used in assessing the } \\
\text { psychology and inter- } \\
\text { ventions experienced } \\
\text { by patients of cancer }\end{array}$ & $\begin{array}{l}\text { Before training the participants were } \\
\text { less confident about using psychologi- } \\
\text { cal techniques and psycho-education } \\
\text { They were well confident about the } \\
\text { ability to give information and break } \\
\text { bad news } \\
\text { After getting training there was sig- } \\
\text { nificant increase in the confidence of } \\
\text { participants in all areas } \\
\text { The highest increase was in their con- } \\
\text { fidence about providing psycho-educa- } \\
\text { tion to support the coping strategies of } \\
\text { patients and carers } \\
\text { There is need to provide constant psy- } \\
\text { chological skills of CNSs }\end{array}$ \\
\hline $\begin{array}{l}\text { (Curtis, EA, } \\
\text { de Vries, J and } \\
\text { Sheerin, FK } \\
\text { 2011) }\end{array}$ & UK & - & $\begin{array}{l}\text { Literature } \\
\text { review }\end{array}$ & $\begin{array}{l}\text {-To identify the new } \\
\text { roles that nursing } \\
\text { leaders must take in } \\
\text { light of new technolo- } \\
\text { gies and development } \\
\text { of incorporation of } \\
\text { nurses in leadership } \\
\text { - To show the man- } \\
\text { ner in which nurse } \\
\text { leaders must position } \\
\text { themselves in effect- } \\
\text { ing change and pro- } \\
\text { viding high standards } \\
\text { for patients }\end{array}$ & $\begin{array}{l}\text { Leadership is a process through which } \\
\text { agents influence subordinates to be- } \\
\text { have in a given manner. } \\
\text { Nursing leadership refers to the ability } \\
\text { of nurses in an empowered position to } \\
\text { influence practice within the hospital } \\
\text { environment } \\
\text { Nursing leadership is developed } \\
\text { through several factors such as experi- } \\
\text { ence in the hospital environment, } \\
\text { training programs, and effective rela- } \\
\text { tionships between nurses and hospital } \\
\text { leaders }\end{array}$ \\
\hline $\begin{array}{c}\text { (Daveson., et al. } \\
\text { 2015) }\end{array}$ & Italy & - & $\begin{array}{l}\text { Literature } \\
\text { review }\end{array}$ & $\begin{array}{l}\text { To assess the ef- } \\
\text { fectiveness and } \\
\text { cost-effectiveness of } \\
\text { specialist palliative } \\
\text { care for adult patients } \\
\text { with advanced illness } \\
\text { receiving care in acute } \\
\text { hospitals and for their } \\
\text { unpaid caregivers }\end{array}$ & $\begin{array}{l}\text { This is protocol to conduct a system- } \\
\text { atic literature review hence no findings } \\
\text { are reported in this paper }\end{array}$ \\
\hline
\end{tabular}




\begin{tabular}{|c|c|c|c|c|c|}
\hline $\begin{array}{l}\text { Duffield., et al. } \\
\text { 2005) }\end{array}$ & Australia & $\begin{array}{l}\text { Work-sampling } \\
\text { study conducted } \\
\text { over } 8 \text { weeks, } \\
\text { Analyzed by us- } \\
\text { ing SPSS, } \\
6 \text { wards private } \\
\text { non profit hos- } \\
\text { pitals, } \\
25 \text { activities } \\
\text { measured }\end{array}$ & $\begin{array}{l}\text { Descriptive } \\
\text { study }\end{array}$ & $\begin{array}{l}\text { To identify and evalu- } \\
\text { ate the understanding } \\
\text { of the CNS and RN as } \\
\text { well as impact of mix } \\
\text { skill method for less } \\
\text { skilled workers, }\end{array}$ & $\begin{array}{l}\text { It is revealed that registered nurses } \\
\text { occupy more area of work than Clinical } \\
\text { Nurse specialists yet they have some } \\
\text { similarities in job } \\
\text { Encourage CNS to share their knowl- } \\
\text { edge and experience with less skilled } \\
\text { staff in order to replace the RNs with } \\
\text { unregulated worker to save the cost. }\end{array}$ \\
\hline $\begin{array}{l}\text { (Ewing and } \\
\text { Booth, 2009) }\end{array}$ & UK & $\begin{array}{l}10 \text { patients } \\
10 \text { family carers } \\
20 \text { health profes- } \\
\text { sionals who } \\
\text { referred to the } \\
\text { SPCS in } \\
\text { the last year }\end{array}$ & $\begin{array}{l}\text { Qualitative } \\
\text { focus groups, } \\
\text { semi structured } \\
\text { interviews, } \\
\text { nonparticipant } \\
\text { observation, } \\
\text { and document } \\
\text { analysis }\end{array}$ & $\begin{array}{l}\text { - To recognize what } \\
\text { worked or not worked } \\
\text { for referrers and pro } \\
\text { suppliers in convey- } \\
\text { ing palliative con- } \\
\text { sideration in healing } \\
\text { center. }\end{array}$ & $\begin{array}{l}\text { This study gives new information on } \\
\text { the interface amongst authority and } \\
\text { generalist procurement of palliative } \\
\text { consideration in an intense healing } \\
\text { facility setting, showing a mutual per- } \\
\text { spective of extra ability and aptitudes } \\
\text { of the SPCS in indication control and } \\
\text { mental bolster, which is exceedingly } \\
\text { esteemed by referrers and is essential } \\
\text { if patients in clinic with complex issues } \\
\text { are to get expert info. } \\
\text { It is especially imperative for this } \\
\text { model of pro palliative consideration to } \\
\text { have the capacity to consolidate ward- } \\
\text { based educating of side effect adminis- } \\
\text { tration as a more esteemed, noticeable, } \\
\text { and continuous piece of their part in } \\
\text { the healing facility setting, tending to } \\
\text { not just the steady turnover of junior } \\
\text { restorative staff additionally the obli- } \\
\text { gations of general staff themselves in } \\
\text { manifestation control. }\end{array}$ \\
\hline $\begin{array}{l}\text { (Fisher, K, } \\
\text { 2006) }\end{array}$ & UK & $\begin{array}{l}\text { Impact of COPD } \\
\text { on } 63 \text { patients }\end{array}$ & $\begin{array}{l}\text { Qualitative and } \\
\text { quantitative } \\
\text { methods used, } \\
\text { to experience } \\
63 \text { patients } \\
\text { with end-stage } \\
\text { COPD }\end{array}$ & $\begin{array}{l}\text {-There is evidence to } \\
\text { suggest that patients } \\
\text { with life-limiting } \\
\text { illness other than } \\
\text { cancer would benefit } \\
\text { from specialist pallia- } \\
\text { tive care services }\end{array}$ & $\begin{array}{l}\text { Many patients with non-malignant dis- } \\
\text { ease experience distressing symptoms } \\
\text { and have unmet palliative care needs } \\
\text { Health care professionals play an im- } \\
\text { portant role in caring for patients with } \\
\text { life-limiting illness } \\
\text { Staff working and palliative care spe- } \\
\text { cialists should work collaboratively to } \\
\text { ensure of patient needs }\end{array}$ \\
\hline $\begin{array}{l}\text { (Forbes, A., } \\
\text { While, A., } \\
\text { Mathes, L., and } \\
\text { Griffiths, P. } \\
\text { 2006). }\end{array}$ & UK & $\begin{array}{c}753 \text { people } \\
\text { invited in six } \\
\text { neurological ser- } \\
\text { vices in England. } \\
616 \text { patients } \\
\text { finally partici- } \\
\text { pated in the final } \\
\text { outcome }\end{array}$ & $\begin{array}{c}\text { A mixed } \\
\text { qualitative and } \\
\text { quantitative } \\
\text { analysis }\end{array}$ & $\begin{array}{l}\text {-To determine the } \\
\text { improvement of } \\
\text { healthcare among } \\
\text { patients with multiple } \\
\text { sclerosis (MS) as a } \\
\text { result of introducing } \\
\text { specialist nurses }\end{array}$ & $\begin{array}{l}\text { Specialist nurses provide more infor- } \\
\text { mation to the patients as opposed to } \\
\text { generalist nurses } \\
\text { With specialist nurses, there is an } \\
\text { increase in the availability of a nurse } \\
\text { when patients need one } \\
\text { Incidences of MS complications such } \\
\text { as pressure ulcers reduce and reduce } \\
\text { physical symptoms. }\end{array}$ \\
\hline
\end{tabular}




\begin{tabular}{|c|c|c|c|c|c|}
\hline $\begin{array}{c}\text { (Foster, J and } \\
\text { Flanders, S } \\
\text { 2014) }\end{array}$ & USA & & $\begin{array}{l}\text { Literature } \\
\text { review }\end{array}$ & $\begin{array}{l}\text {-To identify the chal- } \\
\text { lenges of CNSs in } \\
\text { clinical practice and } \\
\text { factors that limit their } \\
\text { practice }\end{array}$ & $\begin{array}{l}\text { Need for expansion of opportunities of } \\
\text { nurses to lead and foster improvement } \\
\text { in the clinical setting } \\
\text { Nurses require assets such as informa- } \\
\text { tion technology, library resources, and } \\
\text { simulation classrooms to strengthen } \\
\text { their CNS education and acquire spe- } \\
\text { cialization competencies }\end{array}$ \\
\hline $\begin{array}{l}\text { (Gardner and } \\
\text { (Chang and } \\
\text { Duffield, 2007) }\end{array}$ & Australia & $\begin{array}{l}9 \text { advanced prac- } \\
\text { tice nurses ( } 3 \\
\text { acute care hospi- } \\
\text { tals in south east } \\
\text { Queensland) }\end{array}$ & $\begin{array}{l}\text { Qualitative } \\
\text { study, } \\
\text { Interpretive } \\
\text { study. Present- } \\
\text { ed the strong } \\
\text { Model of ad- } \\
\text { vance practice }\end{array}$ & $\begin{array}{l}\text { To identify the ad- } \\
\text { vance practice nurs- } \\
\text { ing system } \\
\text { To identify how nurse } \\
\text { practitioner can be } \\
\text { operationally and leg- } \\
\text { islatively differentiat- } \\
\text { ed from the advanced } \\
\text { practice role. }\end{array}$ & $\begin{array}{l}\text { This study revealed the concern of } \\
\text { nomenclature, of the new advance } \\
\text { nursing system as well as the roles of } \\
\text { specialists in innovative nursing sys- } \\
\text { tem according to the consumer needs }\end{array}$ \\
\hline $\begin{array}{l}\text { (Gerrish., et al. } \\
\text { 2011) }\end{array}$ & England & $\begin{array}{l}23 \text { nurses were } \\
\text { observed and } \\
\text { interviewed for } \\
\text { data collection }\end{array}$ & $\begin{array}{l}\text { Multiple instru- } \\
\text { mental case } \\
\text { study }\end{array}$ & $\begin{array}{l}\text { To analyze the ap- } \\
\text { proaches used by } \\
\text { advanced practice } \\
\text { nurses to promote } \\
\text { evidence-based prac- } \\
\text { tice among clinical } \\
\text { nurses. }\end{array}$ & $\begin{array}{l}\text { The advance practice nurses plays } \\
\text { an important role in promoting the } \\
\text { evidence based activities to the clinical } \\
\text { nurses } \\
\text { The key components of the knowl- } \\
\text { edge brokering are the promoting the } \\
\text { uptake of knowledge and knowledge } \\
\text { management } \\
\text { During knowledge management, relat- } \\
\text { ed evidences are generated, collected, } \\
\text { synthesized, translated, interpreted } \\
\text { and distilled it for intended audience } \\
\text { and reported it in effective way } \\
\text { The knowledge and skills of clinical } \\
\text { nurses was improved by advance prac- } \\
\text { tice nurse by acting as change facilita- } \\
\text { tor, problem solver, teacher and role } \\
\text { model for the clinical nurses }\end{array}$ \\
\hline $\begin{array}{l}\text { (Glen and Wad- } \\
\text { dington 1998). }\end{array}$ & UK & $\begin{array}{c}\text { Only } 2 \text { expe- } \\
\text { rienced staff } \\
\text { nurses to CNS. }\end{array}$ & $\begin{array}{l}\text { Case study, } \\
\text { exploratory, } \\
\text { descriptive. } \\
\text { Using Nichol- } \\
\text { son's (1984) } \\
\text { model of work- } \\
\text { role transition } \\
\text { and Wanous' } \\
\text { (1992) four- } \\
\text { stage model of } \\
\text { organizational } \\
\text { socialization. }\end{array}$ & $\begin{array}{l}\text {-To identify factors } \\
\text { that facilitates or } \\
\text { hinders transition. } \\
\text { - Offer guidelines } \\
\text { relating to appropri- } \\
\text { ate preparation and } \\
\text { supervisory support. }\end{array}$ & $\begin{array}{l}\text { There is paucity of literature relating to } \\
\text { role transition from experienced Staff } \\
\text { Nurse to CNS. } \\
\text { CNS reflected upon their role in } \\
\text { relation to } 4 \text { dimensions of the job: } \\
\text { Working independently, setting goals, } \\
\text { prioritizing the parts of the job, choos- } \\
\text { ing with whom to deal in order to carry } \\
\text { out the job } \\
\text { CNS developed both personally and } \\
\text { professionally, and has demonstrated } \\
\text { adaptation and innovation in the role, } \\
\text { although, role transition is challenging. } \\
\text { There is a great need for role clarity, } \\
\text { support and supervision. }\end{array}$ \\
\hline
\end{tabular}




\begin{tabular}{|c|c|c|c|c|c|}
\hline $\begin{array}{c}\text { (Hibbert, } \\
\text { Al-Sanea, and } \\
\text { Balens, 2012) }\end{array}$ & $\begin{array}{l}\text { Saudi } \\
\text { Arabia }\end{array}$ & $\begin{array}{l}\text { Nurses, Students, } \\
\text { Patient centered } \\
\text { care model }\end{array}$ & $\begin{array}{c}\text { Exploratory } \\
\text { and descriptive } \\
\text { study }\end{array}$ & $\begin{array}{l}\text { Aim of this study is to } \\
\text { provide the perspec- } \\
\text { tive on CNS practice } \\
\text { who develop the } \\
\text { professionally in the } \\
\text { clinical domain as } \\
\text { well as provide them } \\
\text { opportunity to gain } \\
\text { knowledge and skills. }\end{array}$ & $\begin{array}{l}\text { It is found by this study there was } \\
\text { no differences found in nurses self- } \\
\text { concept questionnaire from pre and } \\
\text { post-test phases as well as Transition } \\
\text { programs gave the positive environ- } \\
\text { ment where they can learn and teach } \\
\text { well. }\end{array}$ \\
\hline $\begin{array}{l}\text { (Hodgins, M, } \\
\text { and Boydell, K. } \\
\text { M. 2014). }\end{array}$ & Canada. & $\begin{array}{c}\text { The two authors } \\
\text { of the article }\end{array}$ & $\begin{array}{l}\text { Auto-ethnog- } \\
\text { raphy }\end{array}$ & $\begin{array}{l}\text { Demonstrating the } \\
\text { concept of 'auto-eth- } \\
\text { nography' and writing } \\
\text { reflectively about } \\
\text { ourselves }\end{array}$ & $\begin{array}{l}\text { The paper demonstrates the benefits } \\
\text { of using the art of auto-ethnography } \\
\text { in explaining issues that may evoke } \\
\text { emotions. }\end{array}$ \\
\hline $\begin{array}{l}\text { Im, E.-0. } 2014 . \\
\text { Afaf Ibrahim } \\
\text { Meleis: Transi- } \\
\text { tions Theory. } \\
\text { In: M. R. Alli- } \\
\text { good, ed. Nurs- } \\
\text { ing Theorists } \\
\text { and their Work }\end{array}$ & UK & - & $\begin{array}{l}\text { Literature } \\
\text { review }\end{array}$ & $\begin{array}{l}\text { Analyzing different } \\
\text { theories of nursing } \\
\text { transition }\end{array}$ & $\begin{array}{l}\text { The author identifies different transi- } \\
\text { tion theories and the elements within } \\
\text { them that are applicable in the context } \\
\text { of nursing transition from one role } \\
\text { to another. Issues such as personal } \\
\text { reasons and inadequate education lead } \\
\text { to poor transition }\end{array}$ \\
\hline $\begin{array}{l}\text { (Jack, B, Hillier, } \\
\text { V, Williams, A } \\
\text { and Oldham, J } \\
\text { 2003). }\end{array}$ & UK & $\begin{array}{l}100 \text { cancer } \\
\text { patients }\end{array}$ & $\begin{array}{l}\text { Quantitative } \\
\text { analysis using } \\
\text { Palliative Care } \\
\text { Assessment } \\
\text { (PACA) }\end{array}$ & $\begin{array}{l}\text { Determination of } \\
\text { patient wellness due } \\
\text { to introduction of pal- } \\
\text { liative care teams }\end{array}$ & $\begin{array}{l}\text { There was a statistically significant } \\
\text { improvement in the symptoms of } \\
\text { patients. The patients improved in } \\
\text { anorexia and pain owing to better } \\
\text { management }\end{array}$ \\
\hline $\begin{array}{l}\text { (Jack, Oldham, } \\
\text { and Williams, } \\
\text { 2002) }\end{array}$ & UK & $\begin{array}{l}31 \text { stake holder } \\
\text { across the hospi- } \\
\text { tal setting, } \\
\text { Cross-case analy- } \\
\text { sis were used }\end{array}$ & $\begin{array}{l}\text { Qualitative } \\
\text { research }\end{array}$ & $\begin{array}{l}\text { This study presents } \\
\text { junior staff not fully } \\
\text { aware of the role of } \\
\text { calmative care clinical } \\
\text { nurse specialists. }\end{array}$ & $\begin{array}{l}\text { It is found that Palliative care CNSs } \\
\text { have positive impact on nurses and } \\
\text { doctors which provided the support } \\
\text { and advice on education. } \\
\text { Recognition of de- skilling by the } \\
\text { senior staff who has wider role in CNSs } \\
\text { especially they may have been involved } \\
\text { in the development of job description. } \\
\text { There is a need to explore the educa- } \\
\text { tional input of the CNS, which success- } \\
\text { fully addresses the issues regarding } \\
\text { cancer care. }\end{array}$ \\
\hline $\begin{array}{c}\text { (Kleinpell, R, } \\
\text { Scanlon, A, Hib- } \\
\text { bert, D, Ganz, F, } \\
\text { East, L, Fraser, } \\
\text { D, Wong, F and } \\
\text { Beauchesne, M } \\
\text { 2014). }\end{array}$ & $\begin{array}{l}\text { Worldwide } \\
\text { UK, USA, } \\
\text { Saudi Ara- } \\
\text { bia, Israel, } \\
\text { Canada, }\end{array}$ & - & $\begin{array}{l}\text { Literature } \\
\text { review }\end{array}$ & $\begin{array}{l}\text {-To identify the role } \\
\text { of advanced practice } \\
\text { nurses globally }\end{array}$ & $\begin{array}{l}\text { The role of APRNs is dictated by specif- } \\
\text { ic country regulations. Further, APRN } \\
\text { comprises of several components such } \\
\text { as prescribe medication, perform and } \\
\text { interpret diagnostic testing } \\
\text { APRN differs in different countries } \\
\text { such as USA, Australia, Israel, and } \\
\text { Saudi Arabia. In SA, it is still in its } \\
\text { infancy and makes about } 29 \% \text { of the } \\
\text { nursing workforce }\end{array}$ \\
\hline
\end{tabular}


Journey of Profound Life Lessons, Learning, Change and Self-awareness: Preparation for a Role Transition from a Senior Saudi Registered Nurse to a Specialist Palliative Care Nurse

\begin{tabular}{|c|c|c|c|c|c|}
\hline $\begin{array}{c}\text { (Lang, SV } \\
\text { 2009). }\end{array}$ & UK & & $\begin{array}{l}\text { Experimenta- } \\
\text { tion }\end{array}$ & $\begin{array}{l}\text { Determining the } \\
\text { impact of using elec- } \\
\text { tronic medical records } \\
\text { and the specialist } \\
\text { nurses role }\end{array}$ & $\begin{array}{l}\text { CNSs are vital in the development of } \\
\text { effective processes of adaptation=on } \\
\text { of technology. Their input ensures that } \\
\text { the care has the required elements to } \\
\text { work in a clinical setting. }\end{array}$ \\
\hline $\begin{array}{l}\text { (Leary A., et al., } \\
\text { 2008) }\end{array}$ & UK & $\begin{array}{l}463 \text { self-selected } \\
\text { CNSs of differ- } \\
\text { ent specialties } \\
\text { in it cancer, } \\
\text { palliative, tissue } \\
\text { viability and } \\
\text { heart failure, } 448 \\
\text { from England, } \\
3 \text { in Wales, } 12 \\
\text { in Scotland and } \\
\text { none in Northern } \\
\text { Ireland. } \\
\text { Structures Qurey } \\
\text { language data- } \\
\text { base is used. }\end{array}$ & $\begin{array}{l}\text { Exploratory } \\
\text { longitudinal } \\
\text { study, Qualita- } \\
\text { tive research. }\end{array}$ & $\begin{array}{l}\text { To work on the model } \\
\text { of clinical nurse spe- } \\
\text { cialist in the UK } \\
\text { This study presented } \\
\text { the information } \\
\text { regarding model of } \\
\text { CNS work as well as } \\
\text { used the technique for } \\
\text { knowledge discovery. }\end{array}$ & $\begin{array}{l}\text { Data mining is a techniques of knowl- } \\
\text { edge which used in different profes- } \\
\text { sionals such as information systems } \\
\text { and statisticians. } \\
\text { Model consists of eight dimensions } \\
\text { such as event, data. Context. Temporal, } \\
\text { intervention, emotional effort, outcome } \\
\text { and form. } \\
\text { Majority of the work is in clinical rep- } \\
\text { resenting } 68 \% \text { of the events and } 24 \% \\
\text { of administrative. }\end{array}$ \\
\hline $\begin{array}{l}\text { (Lewandowski } \\
\text { and Kathleen } \\
\text { 2009) }\end{array}$ & Ohio, USA & $\begin{array}{c}753 \text { anec- } \\
\text { dotal articles, } \\
277 \text { research } \\
\text { articles, } 62 \text { dis- } \\
\text { sertation/thesis } \\
\text { abstracts and } \\
181 \text { abstracts } \\
\text { presentation } \\
\text { were analyzed } \\
\text { thoroughly }\end{array}$ & $\begin{array}{l}\text { Literature } \\
\text { review }\end{array}$ & $\begin{array}{l}\text { To identify the clini- } \\
\text { cal areas of clinical } \\
\text { nurse specialist (CNS) } \\
\text { practice }\end{array}$ & $\begin{array}{l}\text { Three clinical area of clinical nurse } \\
\text { specialist (CNS) practice were found } \\
\text { The first area was the proper man- } \\
\text { agement of complex and vulnerable } \\
\text { populations } \\
\text { The second area was the education and } \\
\text { support of interdisciplinary staff. } \\
\text { The third area was the facilitate change } \\
\text { and innovation within healthcare } \\
\text { systems }\end{array}$ \\
\hline $\begin{array}{l}\text { (Lungton, J and } \\
\text { McIntyre, R } \\
\text { 2005) }\end{array}$ & UK & $\begin{array}{l}\text { Palliative nurses } \\
\text { in several set- } \\
\text { tings in different } \\
\text { case studies }\end{array}$ & Qualitative & $\begin{array}{l}\text {-To demonstrate the } \\
\text { key values that pallia- } \\
\text { tive nurses must have } \\
\text { in a clinical environ- } \\
\text { ment } \\
\text { - To demonstrate the } \\
\text { roles that palliative } \\
\text { nurses are involved } \\
\text { in when working in a } \\
\text { clinical setting }\end{array}$ & $\begin{array}{l}\text { Palliative nurses within the hospital } \\
\text { setting work in a supportive and advi- } \\
\text { sory role. As such, they always work in } \\
\text { teams and being successful needs them } \\
\text { to invest time in understanding team } \\
\text { members } \\
\text { Palliative nurses must be flexible in ap- } \\
\text { plication of their knowledge in order to } \\
\text { be successful and even accommodate } \\
\text { their fellow team members } \\
\text { Transitioning to the new role takes } \\
\text { time. While fresh graduates feel } \\
\text { confident to even open consultancies, } \\
\text { they need the experience of working in } \\
\text { an acute hospital setting before doing } \\
\text { these duties on their own. }\end{array}$ \\
\hline
\end{tabular}




\begin{tabular}{|c|c|c|c|c|c|}
\hline $\begin{array}{l}\text { (Malhotra, P. } \\
\text { 2013). }\end{array}$ & USA & - & $\begin{array}{l}\text { Auto-ethnog- } \\
\text { raphy }\end{array}$ & $\begin{array}{l}\text { To demonstrate the } \\
\text { journey of transition } \\
\text { of nurses from one } \\
\text { country to another } \\
\text { through auto-ethno- } \\
\text { graphic methodology }\end{array}$ & $\begin{array}{l}\text { Using auto ethnography, the author } \\
\text { narrates his journey from Mumbai } \\
\text { India and visiting his adaptive agency } \\
\text { in India. Through a long search, the } \\
\text { author explains how he searched } \\
\text { through groups to try and reconstruct } \\
\text { his journey }\end{array}$ \\
\hline $\begin{array}{l}\text { (Manning, L } \\
\text { and Neville, S } \\
\text { 2009) }\end{array}$ & $\begin{array}{l}\text { New Zea- } \\
\text { land }\end{array}$ & $\begin{array}{c}\text { Eight clinical } \\
\text { nurse educators }\end{array}$ & $\begin{array}{l}\text { Qualitative } \\
\text { descriptive } \\
\text { methodology }\end{array}$ & $\begin{array}{l}\text { To identify the chal- } \\
\text { lenges of staff nurses } \\
\text { when transitioning to } \\
\text { clinical educators }\end{array}$ & $\begin{array}{l}\text { Every transition has its complica- } \\
\text { tion. Having been in practice, staff } \\
\text { nurses expected that the role of a } \\
\text { clinical nurse educator would be easy. } \\
\text { However, they found that it was quite } \\
\text { difficult to transition. }\end{array}$ \\
\hline $\begin{array}{l}\text { (Meleis, AI, } \\
\text { Sawyer, LM, } \\
\text { Im, E-O, Mes- } \\
\text { sias, DKH and } \\
\text { Schumacher, K } \\
\text { 2000). }\end{array}$ & USA & & $\begin{array}{l}\text { Literature } \\
\text { review }\end{array}$ & $\begin{array}{l}\text { Analysis of transi- } \\
\text { tion of nurses using } \\
\text { middle-range theory }\end{array}$ & $\begin{array}{l}\text { Middle-range theory of transitions } \\
\text { has types and patterns of transitions } \\
\text { together with transition experiences } \\
\text { that facilitate or inhibit the process of } \\
\text { transition. }\end{array}$ \\
\hline $\begin{array}{l}\text { (Mishelmovich, } \\
\text { Arber, and Ode- } \\
\text { lius, 2015). }\end{array}$ & UK & $\begin{array}{l}4 \text { Cancer CNS, } 6 \\
\text { PCNS, who were } \\
\text { working in NHS } \\
\text { trust. }\end{array}$ & $\begin{array}{c}\text { Qualitative } \\
\text { Research, De- } \\
\text { scriptive study. } \\
\\
\text { Semi structured } \\
\text { interviews for } \\
1 \text { hour, Audio } \\
\text { recorded. }\end{array}$ & $\begin{array}{l}\text { To explore specialist } \\
\text { cancer and palliative } \\
\text { care nurses' lived ex- } \\
\text { perience of delivering } \\
\text { significant news to pa- } \\
\text { tients with advanced } \\
\text { cancer. }\end{array}$ & $\begin{array}{l}\text { This study revealed that CNSs felt con- } \\
\text { fident while delivering the significant } \\
\text { news and that building the trustworthy } \\
\text { relationship with patients removed the } \\
\text { communication gap and make it easier. } \\
\text { CNSs used the guidelines flexibly, } \\
\text { which helped them to implement this } \\
\text { effectively. } \\
\text { They found that breaking news related } \\
\text { to terminal prognosis for younger } \\
\text { patients challenging. } \\
\text { Four themes emerged: The importance } \\
\text { of relationships. Perspective taking. } \\
\text { Ways to break significant news. Feeling } \\
\text { prepared and putting yourself forward. }\end{array}$ \\
\hline $\begin{array}{l}\text { (Monroe, B and } \\
\text { Speck, P 2006) }\end{array}$ & UK & $\begin{array}{l}\text { Palliative nurses } \\
\text { in several set- } \\
\text { tings in different } \\
\text { case studies }\end{array}$ & Qualitative & $\begin{array}{l}\text {-to demonstrate the } \\
\text { key values that pallia- } \\
\text { tive nurses must have } \\
\text { in a clinical environ- } \\
\text { ment } \\
\text { - to demonstrate the } \\
\text { roles that palliative } \\
\text { nurses are involved } \\
\text { in when working in a } \\
\text { clinical setting }\end{array}$ & $\begin{array}{l}\text { Palliative nurses within the hospital } \\
\text { setting work in a supportive and advi- } \\
\text { sory role. As such, they always work in } \\
\text { teams and being successful needs them } \\
\text { to invest time in understanding team } \\
\text { members } \\
\text { Palliative nurses must be flexible in ap- } \\
\text { plication of their knowledge in order to } \\
\text { be successful and even accommodate } \\
\text { their fellow team members } \\
\text { Transitioning to the new role takes } \\
\text { time. While fresh graduates feel } \\
\text { confident to even open consultancies, } \\
\text { they need the experience of working in } \\
\text { an acute hospital setting before doing } \\
\text { these duties on their own. }\end{array}$ \\
\hline
\end{tabular}




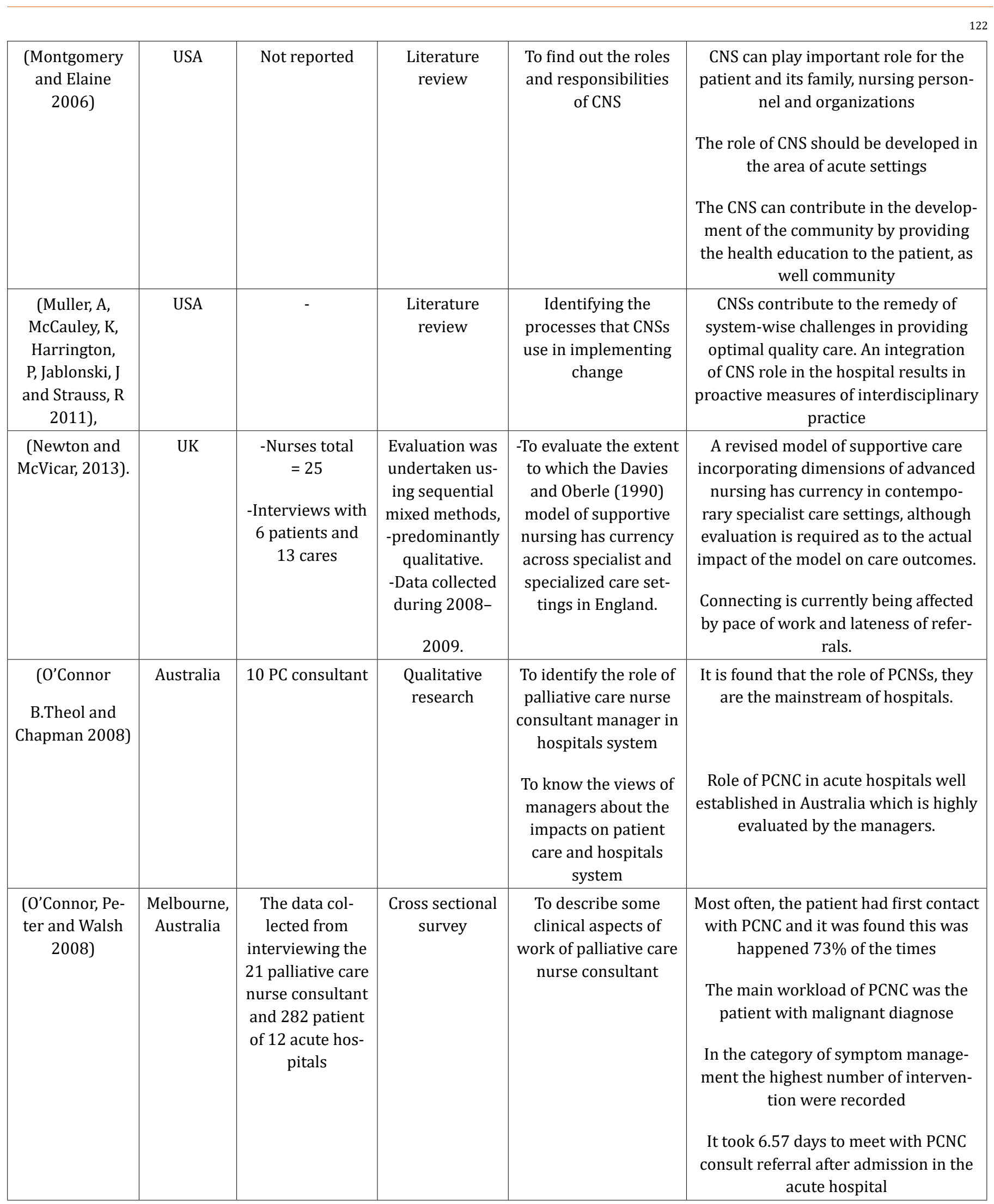




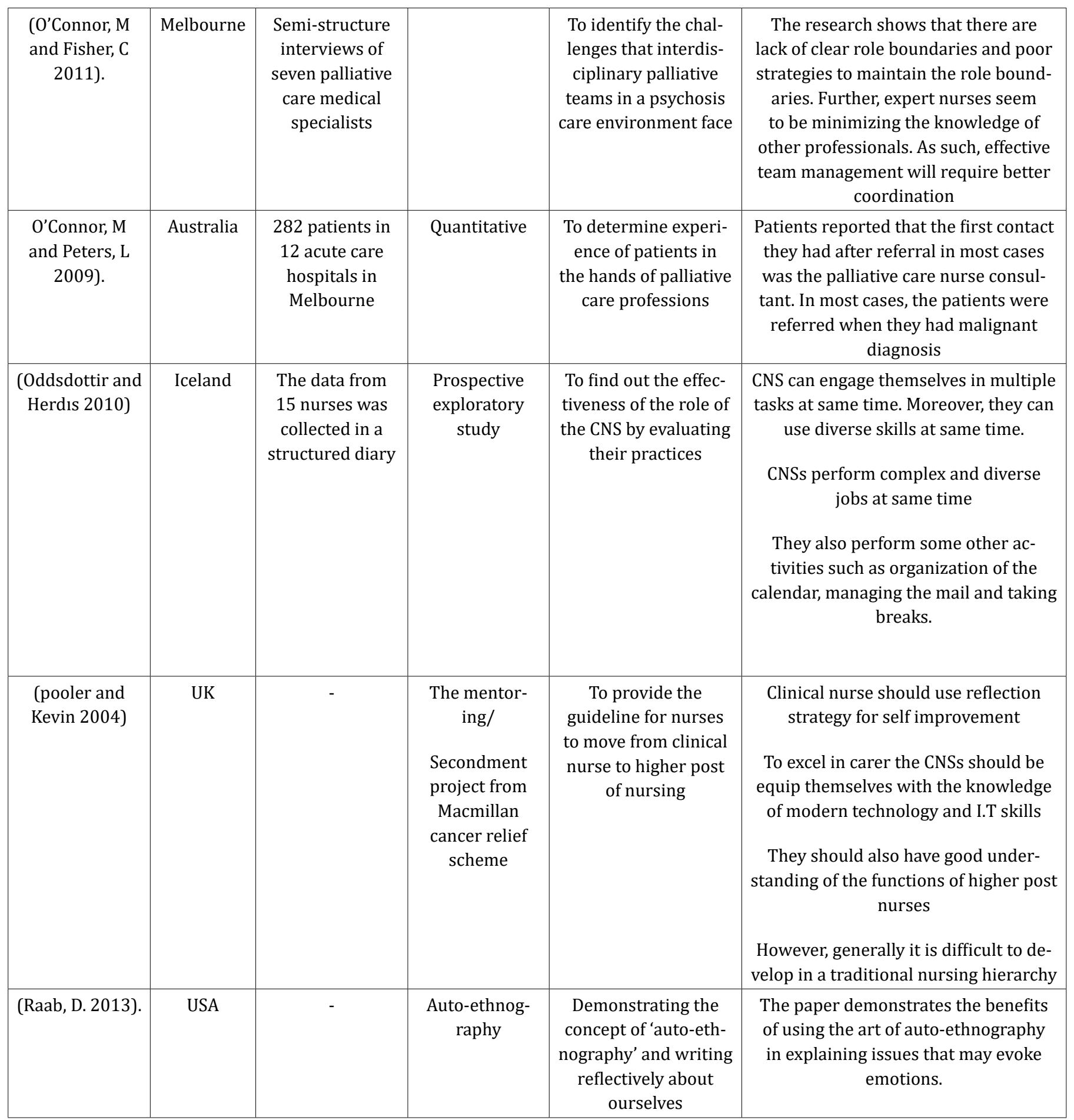

Citation: Fatimah Alabduljabbar. "Journey of Profound Life Lessons, Learning, Change and Self-awareness: Preparation for a Role Transition from a Senior Saudi Registered Nurse to a Specialist Palliative Care Nurse". Acta Scientific Medical Sciences 4.11 (2020): 112-137. 


\begin{tabular}{|c|c|c|c|c|c|}
\hline $\begin{array}{c}\text { (Skilbeck and } \\
\text { Payne, 2003) }\end{array}$ & UK & $\begin{array}{c}\text { Methods used } \\
\text { such as CINAHI, } \\
\text { MEDLINE, ASSIA } \\
\text { CD-ROM }\end{array}$ & $\begin{array}{c}\text { Qualitative } \\
\text { Research, De- } \\
\text { scriptive study }\end{array}$ & $\begin{array}{l}\text { This study focus on } \\
\text { the role of providing } \\
\text { the specialist pal- } \\
\text { liative care to cancer } \\
\text { patients across the } \\
\text { United Kingdom. } \\
\text { The main objective } \\
\text { of this study is to de- } \\
\text { scribe the emotional } \\
\text { care and supportive } \\
\text { behavior of patients } \\
\text { by providing them } \\
\text { advance cancer care }\end{array}$ & $\begin{array}{l}\text { It is divulged that lack of transparency } \\
\text { about the terms used in emotional care } \\
\text { and support for cancer patients. } \\
\text { CNSs used the guidelines, which helped } \\
\text { them to implement practices regard- } \\
\text { ing emotional care and support for } \\
\text { cancer patients, which create the social } \\
\text { interaction. } \\
\text { By using the effective parameters built } \\
\text { nurse-patient relationship as well as } \\
\text { use the effective communication skill } \\
\text { in health care context. }\end{array}$ \\
\hline $\begin{array}{c}\text { (Skilbeck., et al. } \\
\text { 2002) }\end{array}$ & UK & $\begin{array}{l}\text { Generic hospital- } \\
\text { based services } \\
\text { and community- } \\
\text { based services. } \\
\text { Are courses for } \\
\text { the study of Mac- } \\
\text { millan nursing } \\
\text { services based } \\
\text { on geographical } \\
\text { location, teams, } \\
\text { maturity ser- } \\
\text { vices, and mem- } \\
\text { bers' willingness } \\
\text { to participate } \\
\text { in the research } \\
\text { work } \\
\text { 12 Macmillan } \\
\text { teams for } 8 \\
\text { weeks with each } \\
\text { team, } 7 \text { hospital } \\
\text { teams }\end{array}$ & $\begin{array}{c}\text { Prospective, } \\
\text { longitudinal, } \\
\text { comparative } \\
\text { case study and } \\
\text { used a variety } \\
\text { of } \\
\text { Quantitative } \\
\text { and qualitative } \\
\text { methods }\end{array}$ & $\begin{array}{l}\text { - To depict and look } \\
\text { at the structure and } \\
\text { association of singular } \\
\text { Macmillan Nurse } \\
\text { administrations gave } \\
\text { in two districts in the } \\
\text { United Kingdom; } \\
\text { - To distinguish the } \\
\text { uptake of administra- } \\
\text { tions, exclusively and } \\
\text { on the whole; } \\
\text { - To depict the en- } \\
\text { counters of patients } \\
\text { and relatives some- } \\
\text { where a Macmillan } \\
\text { Nurse is included in } \\
\text { consideration, as far } \\
\text { as personal satisfac- } \\
\text { tion, mental dismal- } \\
\text { ness, indications and } \\
\text { issues, fulfilment with } \\
\text { consideration, and } \\
\text { spot of death; } \\
\text { - To decide the } \\
\text { expense and asset } \\
\text { use connected with } \\
\text { Macmillan Nurse } \\
\text { administrations inside } \\
\text { and between the } \\
\text { doctor's facility and } \\
\text { group settings; and to } \\
\text { investigate how Mac- } \\
\text { millan Nurse adminis- } \\
\text { trations impact other } \\
\text { expert carers and } \\
\text { the advancement of } \\
\text { neighborhood strat- } \\
\text { egy and arranging. }\end{array}$ & $\begin{array}{l}\text { The primary wellspring of referral to } \\
\text { the Macmillan nursing administrations } \\
\text { was human services experts in the } \\
\text { clinic setting, whether it is ward-based } \\
\text { staff, outpatient, or other medical care- } \\
\text { taker authorities. } \\
\text { Macmillan Nurse groups have been } \\
\text { fruitful in accessing important pa- } \\
\text { tients, whether this is toward the end } \\
\text { of a patient's life or prior in the ailment } \\
\text { direction. } \\
\text { Similarly, as with any administration } \\
\text { that gives an unpredictable arrange- } \\
\text { ment of mediations, the Macmillan } \\
\text { groups need to adjust and build up the } \\
\text { administrations in every setting. } \\
\text { Whilst it is unmistakably vital for the } \\
\text { advancement of Macmillan administra- } \\
\text { tion to be customized to the nearby } \\
\text { conditions, along these lines upgrad- } \\
\text { ing value of access to the administra- } \\
\text { tions, the proof on assorted qualities } \\
\text { proposes that at times, more grounded } \\
\text { direction, in association with both } \\
\text { Macmillan Cancer Relief and center } \\
\text { suppliers, might be advocated. }\end{array}$ \\
\hline
\end{tabular}




\begin{tabular}{|c|c|c|c|c|c|}
\hline $\begin{array}{c}\text { (Spoelsta and } \\
\text { Robbins, 2010) }\end{array}$ & USA & $\begin{array}{l}24 \text { students in } \\
\text { two-credit, web- } \\
\text { based role devel- } \\
\text { opment course } \\
\text { in a Master's of } \\
\text { Science in Nurs- } \\
\text { ing program at a } \\
\text { large Midwest- } \\
\text { ern university. }\end{array}$ & $\begin{array}{c}\text { Qualitative } \\
\text { research, De- } \\
\text { scriptive, } \\
\text { Exploratory } \\
\text { Study. } \\
\text { Questionnaire, } \\
\text { interview based } \\
\text { with structured } \\
\text { questions. }\end{array}$ & $\begin{array}{l}\text { To describe and sup- } \\
\text { port the role transi- } \\
\text { tion to APN role of } \\
\text { students enrolled in } \\
\text { a graduate-level role } \\
\text { development course } \\
\text { early in the education- } \\
\text { al period by increas- } \\
\text { ing their awareness of } \\
\text { the role. }\end{array}$ & $\begin{array}{l}\text { This study based on } 7 \text { APN core com- } \\
\text { petencies, which provide the student } \\
\text { with new effective learning strategies } \\
\text { as well as for teachers. Students had } \\
\text { developed an understanding of the } \\
\text { core competencies and complexity } \\
\text { of the role, beginning role transition } \\
\text { occurred. } \\
\text { Three sub- themes 1) building a frame- } \\
\text { work for nursing practice, 2) direct } \\
\text { patient care, and 3) comprehension } \\
\text { and exemplification of professional } \\
\text { responsibilities } \\
\text { The study has implication for nursing } \\
\text { educators interested in developing } \\
\text { role transition early in the educational } \\
\text { process, as course design supports } \\
\text { transition. }\end{array}$ \\
\hline $\begin{array}{l}\text { (Taylor and } \\
\text { Chadwick, } \\
\text { 2015) }\end{array}$ & UK & $\begin{array}{l}\text { Semi structured } \\
\text { questionnaire } \\
\text { and interviews }\end{array}$ & $\begin{array}{c}\text { Explanatory } \\
\text { study }\end{array}$ & $\begin{array}{l}\text { Purpose of this study } \\
\text { is to identify the dif- } \\
\text { ficulties of palliative } \\
\text { care in the hospitals } \\
\text { and its impact on } \\
\text { patients }\end{array}$ & $\begin{array}{l}\text { This study found the reason to know } \\
\text { how difficult it can be for doctors to } \\
\text { tell the truth, which is the main reason } \\
\text { why palliative care is difficult in hos- } \\
\text { pitals as well as explored the learning } \\
\text { techniques for students. } \\
\text { Hospitals are considered as horrible } \\
\text { place to be, at the same time it means } \\
\text { heaven to someone. }\end{array}$ \\
\hline
\end{tabular}




\begin{tabular}{|c|c|c|c|c|c|}
\hline $\begin{array}{l}\text { (Teno and Con- } \\
\text { ner 2009) }\end{array}$ & USA & $\begin{array}{c}\text { Study of } 1 \\
\text { patient's disease } \\
\text { was carried out }\end{array}$ & Case study & $\begin{array}{l}\text { To identify the sce- } \\
\text { narios when to use } \\
\text { hospital based pallia- } \\
\text { tive care services and } \\
\text { when to use hospice } \\
\text { program for a patient }\end{array}$ & $\begin{array}{l}\text { The selection of a hospital based pal- } \\
\text { liative care service or hospice program } \\
\text { depends upon the needs and the goals } \\
\text { of the patient and his/her family. } \\
\text { There is significant variations in the } \\
\text { hospital based palliative services } \\
\text { The hospice service is composed of } \\
\text { Palliative Care Organization Standards } \\
\text { of Practice for Hospice Programs, Pal- } \\
\text { liative Care Organization Standards } \\
\text { of Practice for Hospice Programs and } \\
\text { reimbursements } \\
\text { It was found that if initially a patient } \\
\text { is referred to hospital based palliative } \\
\text { service, then during treatment there } \\
\text { will be point when patient will prefer } \\
\text { to be referred to the hospice service } \\
\text { The patient, their family and physician } \\
\text { should choose a publically reported } \\
\text { hospice program because there is also } \\
\text { many variations in the hospice services }\end{array}$ \\
\hline $\begin{array}{c}\text { (Warnock., et } \\
\text { al. 2010). }\end{array}$ & UK & $\begin{array}{l}\text {-Fifty-nine inpa- } \\
\text { tient areas } \\
\text {-335 } \\
\text { questionnaires }\end{array}$ & $\begin{array}{l}\text { A descriptive } \\
\text { survey design } \\
\text { was adopted } \\
\text { using a ques- } \\
\text { tionnaire } \\
\text { to generate } \\
\text { quantitative } \\
\text { and qualitative } \\
\text { data }\end{array}$ & $\begin{array}{l}\text {-explore the role of } \\
\text { the nurse in the pro- } \\
\text { cess of breaking bad } \\
\text { news in the inpatient } \\
\text { clinical setting } \\
\text {-The provision of edu- } \\
\text { cation and support for } \\
\text { nurses carrying out } \\
\text { this role. }\end{array}$ & $\begin{array}{l}\text { Guidance for breaking bad news } \\
\text { should encompass the whole process } \\
\text { of doing this } \\
\text { Acknowledge the challenges nurses } \\
\text { face in the inpatient clinical area. } \\
\text { Developments in education and } \\
\text { support are required that reflect the } \\
\text { challenges that nurses encounter in the } \\
\text { inpatient care setting. }\end{array}$ \\
\hline
\end{tabular}

Inclusion and exclusion criteria (IEC)

Strict IEC allow more precision and a more focus on the topic searched when determining which papers to include. I used The Critical Appraisal Skills Programme (CASP qualitative checklist) [10] to appraise the quality and evidence for inclusion. It approaches research in 3 steps:

- $\quad$ Is the study valid?

- What are the results?

- $\quad$ Are the results useful?

As well as the guide from the student learning center at Flinders University considering the content, context in discipline, methodology, author and relevance (Figure 1 and 2).
No time frame applied while searching, but the articles included:

- $\quad$ Studies published in English-language.

- $\quad$ Studies contained primary and secondary research data.

- $\quad$ Studies focused on SN's (with a qualification in oncology nursing or palliative and EOL care) role transition from RN to SPCN including (CNS, CNC, APN) their roles, skills, and challenges in acute hospital settings. Also, stakeholders, patients, doctors and nurses (generalists and specialists) perception of these areas of the SPCN work.

- $\quad$ Studies involve SPCN care for adult patients (18 years and older) in acute settings.

- Studies related to the educational preparation of RN for a role transition to SPCN. 
Things to consider when evaluating a reference:

Content

Good arguments Yes / No

Shows evidence for claims Yes / No

Reliable Yes/No

Shows limitations Yes / No

Biased Yes/No

Strong content Yes / No

Weak content Yes / No
Context in discipline:

Landmark article Yes / No

Useful contribution to field Yes / No

Agrees with current thought Yes / No

Contradicts current thought Yes / No

Good introduction to field Yes / No

Figure 1: Evaluation of references.

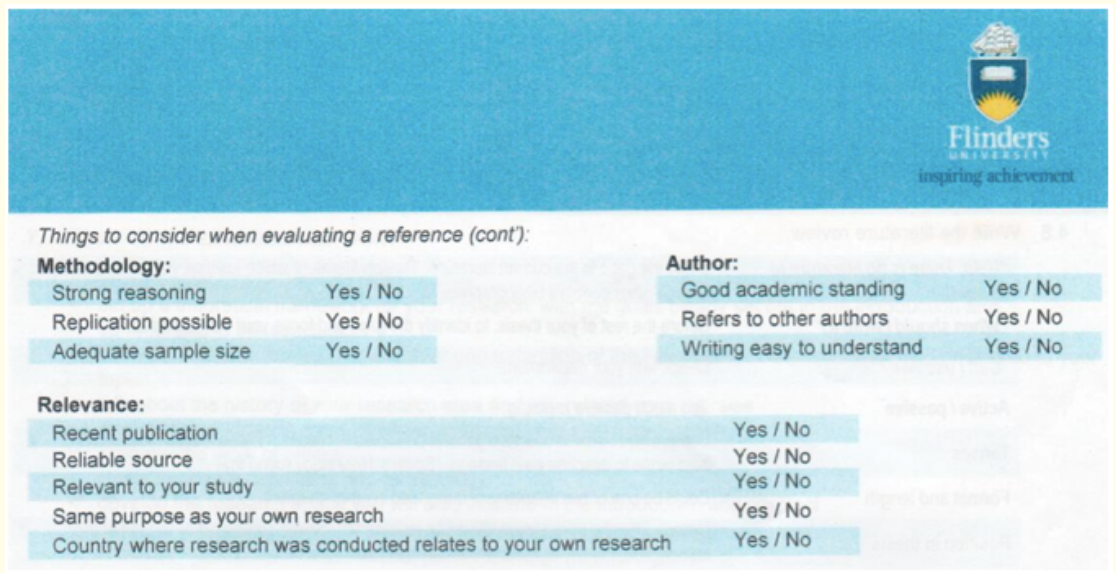

Figure 2: Evaluation of references.

\section{Exclusion}

Non-English papers were excluded; those involve care for children (less than 18 years), and those related to the preparation of graduate nursing student and new graduates for a role transition to $\mathrm{RN}$.

\section{Analysis}

Different themes emerged from the literature and grouped under the main focus areas (role transition, roles, skills, challenges, advantages and disadvantages of the SPCN in hospitals). These constitute my critique of the literature review as part of my preparation transition journey.

Introducing the author and her transition story

As I wonder like Alice in wonderland "if I've been changed in the night? Let me think. Was I the same when I got up this morning? I almost think I can remember feeling a little different. But if I'm not the same, the next question is 'Who in the world am I?' Ah, that's the great puzzle!" That's why I do not write her story in first person.
She is like "a butterfly, beautiful and powerfully quiet" [78]. Like "Alice in wonderland", she was vibrant, curious and caring child, running to help everybody near and far with a kind heart and sharp mind. Her teachers called her the "silent hero". She grew with her dream to be a doctor in a medical team. Owing to adversities, she had to study nursing in Asia despite winning a scholarship to study medicine in Australia. This did not stop her from pursuing the dream to find her true self and her destiny. She looks older and wiser beyond her age in each stage of her life, she has been told all the time. So, it would not be strange, telling others humbly her tale.

After graduating with honor degree, her professional journey started as a 'bee' (RN in 2007). She worked mainly 12 hours shifts in hospital surgical-medical wards caring for patients, what a blessing gift! They were mostly elderlies, sick with chronic conditions, bedridden and at the end of their lives. She worked as a pain management link nurse and a clinical resource nurse (CRN) while working full time at bedside; but she enjoyed doing those despite the long hours, as she has a passion for lifelong learning and searching, education, safety and quality improvement. She is dedi- 
Journey of Profound Life Lessons, Learning, Change and Self-awareness: Preparation for a Role Transition from a Senior Saudi Registered Nurse to a Specialist Palliative Care Nurse

cated, hard worker, with high tenacity and passion to do whatever she can to improve others life. As an ELNEC trainer, she took the end of life nursing education consortium course in 2013 in preparation to be a SPCN.

Surprisingly, a professional development journey took her overseas to Australia to prepare for SPCN role. The transition was not without its fair share of complexities and pain. Hence, she felt like "Alice in Wonderland" falling into a deep hole, facing her destiny. Her experiences with people, books, emotions, and reactions sent her deeper into a 'personal-research mission'.

While she is not good at 'talking' about herself, her 'personal writing' has been her best companion over the years. So, it is worth reading comments from her patients and colleagues to understand her better. An extract from her personal statement (2014) is available (Figure 3).

\section{Counselling the author in transition:}

As a 'counselor' for my self in this journey, I use the transition model because it provides framework to understand those in transitions while considering the 4 S's coping system (Figure 4[63]) .

Additionally, I use the main concepts of the Middle Range theory of transition (Figure 5 [49]), that sheds light on my transition while providing nursing care for patients and their families who are in transitions too.

While individuals appraisal of their own transition is important, I perform two kinds of appraisals simultaneously [41]. All of those are integrated and compared with the lierature review.

One of my patients sent an appreciation letter written on it: " Good morning, I would like to extend my appreciation to RN Fatimah Abdul-Jabbar ID \# (...) from (...) unit (female medical ward) for her outstanding care during my admission as a case of pancreatitis, she was absolutely professional, respectful, with unlimited communication skills which personally made me so proud of her, She did help me lots during this admission psychologically and physically. Whenever she attended me she was always with nice smile, so peaceful, reassuring and never stopped asking "is there anything that I can do for you to let you feel better?"

Honestly my words cannot help in rewarding her for what she deserve as she really touched my

heart with her outstanding care, behavior \& attitude. Definitely she adds great value to (...) team members and to (...). Well done Fatimah and keep it up, God blesses you and your family".

Another appreciation letter sent by one of our internal medicine consultant to my supervisor written on it: "Good morning, I would like to acknowledge and personally thanks Fatimah Al-Abdul-Jabbar for her excellent work and bedside manner, my patients cannot stop telling me about her wonderful work ethic and empathic approach to patient care. I have heard this many times from patients previously. Thank you Fatimah and God bless you for your sincere and heart full nursing care.

Figure 3: Appreciation letters, extract from author personal statement 2014.

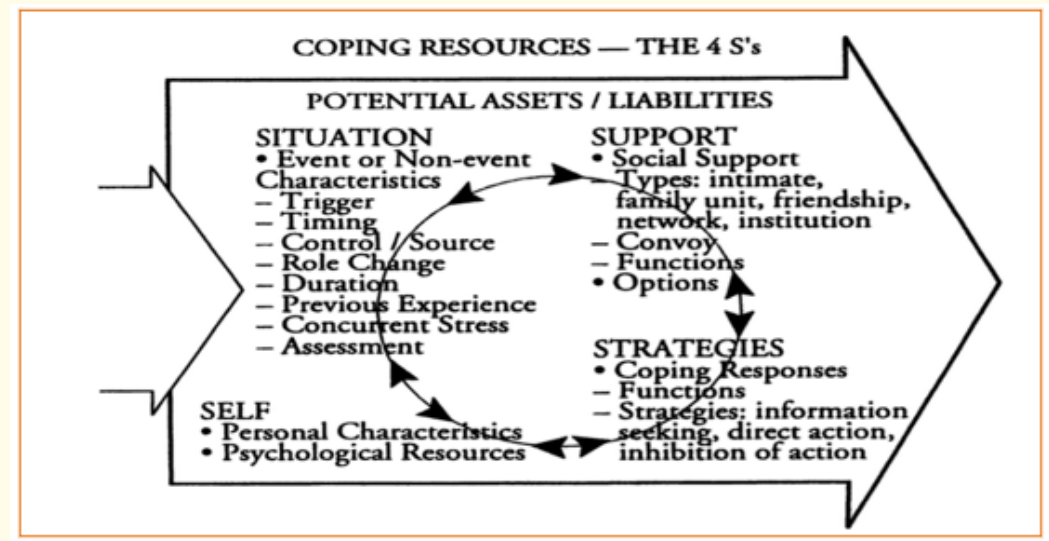

Figure 4: Coping resources-The 4S's, Schlossberg 2005. 


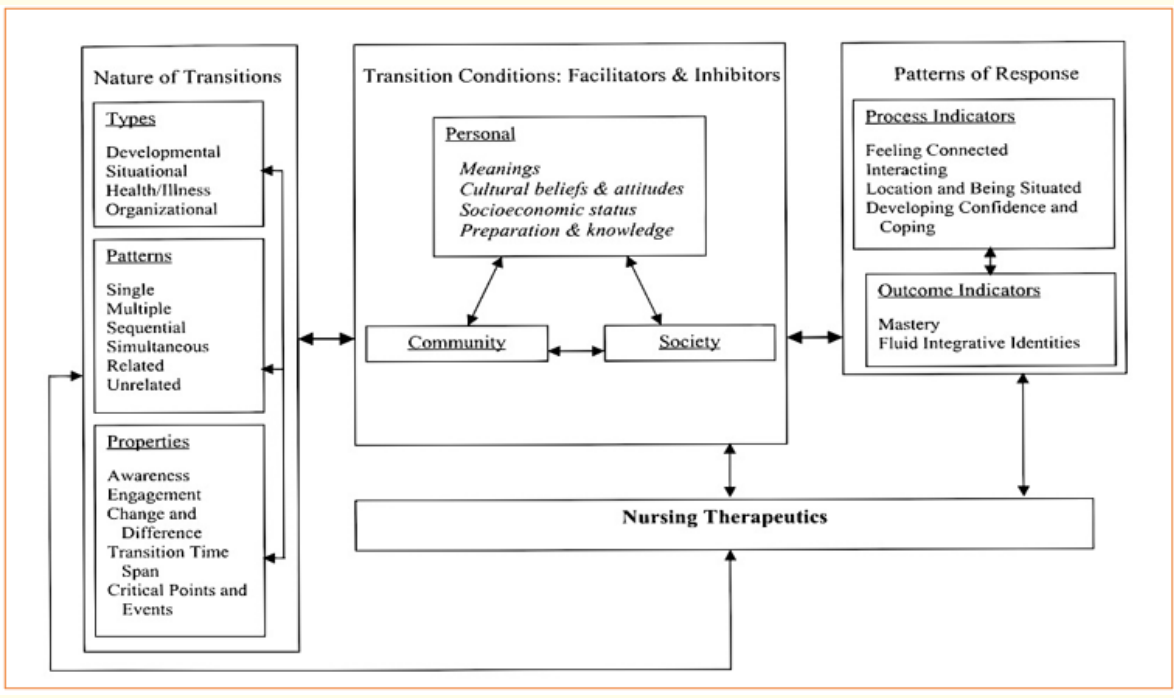

Figure 5: The Middle Range theory of transit (Meleis., et al. 2000).

\section{Literature Review}

Transitions and role transition

Transition is never a singular event and different people undergo unique processes in their transitions [6]. From my journey, I concur that it is an individualized process and you cannot put an exact timeframe for it. Moving from SA to Australia, my patterns gradually change owing to the new roles, identity, ability, and relationships that I have to forge in my new environment [6]. For successful transitioning, I was aware that a nurse must carefully undergo the process of socialization into his/her professional role [6]. I was required to internalize the norms of the people I met into my self-conception and behavior.

My transition is multidimensional including events (traveling overseas, studying in another university and culture, role change, sickness, seconded to a new company, mother of transitioning son entering school) and non-event transitions (e.g. personal things that occur internally like increased spirituality, self-awareness and identity perception) [28]. For the self-variables, I do have the personal characteristics and psychological resources needed to overcome any challenge in my life as a woman. Although have a good supportive network, I felt that fighting for my right to seek the highest truest expression for my self as a human did not go well, instead misunderstood.

In my Primary appraisal, I perceive my transition as positive, challenging opportunity, not healthy and indeed, 'fascinating' shock, but later on it became an 'insightful' journey with all its adversities and miracles. It was not without hindrances. As identified by transition theory, personal conditions such as cultural beliefs, preparation, and knowledge were major hindrances to a successful transition into my new role. Cultural issues were especially significant since I was moving to a country with a different set of cultures that are far from those of SA. Other factors can act as a barrier too. For example, lacking the opportunity for clinical experience (e.g. during mostly an online masters degree programs) or due to lack of clinical practicum settings, physical resources and funding for students [23]. I faced some of those initially, but was blessed to be able to change my situation later on.

According to Rosser., et al. [61], the role of a mentor is essential in the development of SPCN. Unfortunately I was a witness of the dire shortage of CNSs to mentor students [23]. This has resulted in challenges for students who wish to transition to SPCN [25]. The contribution of mentors is further enhanced by their contribution to critical thinking and a transitioning mindset of the student $[2,47]$.

The secondary appraisal seems to be an ongoing process throughout the transition where I assess my coping resources while using different strategies (e.g. praying and other self-care strategies), to overcome those odds in my life. Self-care is important to SPCN [76]. However, as the scope of this paper does not cover those, I discuss them more in my reflection paper.

\section{SPCN roles}

While searching the literature, I was thinking of my future roles as SPCN to be prepared to what would be expected from me. It became clear from the literature that I would play supportive, advisory and consultative roles. My daily duties will be to ensure that I 
am available to HPs to provide both expertise and consultation on issues to do with seriously ill patients [70]. In my supportive role, I will use my clinical expertise in pain and symptoms management $[34,54,58]$.

Further, I will be an essential link to patients and staff in providing education and other services together with being an advocates for quality health [56]. This role is especially important for me since providing quality healthcare is one of my passions. Other than such technical areas, I will also give my expertise in normalizing emotional situations involving patients and their families [42].

Patients describe our work as advance nurse practitioners as important especially in the area of providing information concerning diseases, assistance in communication, emotional support and availability of timely help $[67,68]$. Further, some patients pointed to the need for our involvement at an early stage of their illness $[43,67]$. I can testify to the fact that when SPCNs get involved in patients' cases (though most of the times at late stages), they provide vital information to nurses and physicians and I have witnessed numerous positive turnarounds of the patients. Further, they act as an important link in advising patients concerning information received from doctors [64]. In their expanded role, SPCNs act in leadership capacity as change agents when advocating for better quality of service for the patients $[26,45,52,53]$.

My job does not seem to be ending with dealing with patients. In trying to anchor SPCN in nursing, they also take up administrative roles. In my journey, I hope to make an administrative contribution in demystifying the role of an SPCN by giving the needed information about the role to allow receiving the much-deserved recognition [13]. To further my knowledge, and as I have been working as CRN, I have found myself spending and will spend a lot of my free time researching on new technologies and areas of expertise that can benefit the patients [69].

\section{Challenges}

Despite our critical roles, we still face several challenges. As the role continues to develop, pioneers are faced with the complexity of what they should do and lack of clarity on their specific roles $[7,39]$. Most UK hospitals have been rethinking the role of CNSs owing to what they claim as 'expensive services' [42]. There are also criticisms that direct care provided by CNSs is indistinguishable from that provided by general RNs [43].

In SA, the best nurses can get to transition to CNSs is on the job training [31]. Even in developed countries, the relative novelty of this role means that most schools and hospitals have not developed clear requirements for one to qualify as a CNS [23].
Most administrations are slow in accepting and appreciating the role played by SPCNs, which leads them providing little or no support [35]. Further, the hospital setting has been viewed as providing very little support to provide palliative care in terms of coordination with other practitioners and the general environment [18]. This is on top of the specialized nurses having to grumble with shortage of staff and increased workload [20,55], which adversely affects the time available for them. This is the case in SA as well, on top of living in male dominated medical system [31].

The novelty of CNS means that few people understand this area of practice. Rosser., et al. [61] state that as a result of this, CNSs feel isolated both professionally and in their personal lives. The administration is often reluctant to make changes while in other cases $[24,27]$, financial constraints lead to funding of CNS related research being abandoned.

\section{Skills}

As an SPCN, I have advanced knowledge and skills enabling me to perform at an expanded level of healthcare provision [66]. The knowledge I accumulated as an RN and later after transition to an SPCN has enabled me become more skilled. As such, my judgment and discretion on clinical issues are high when fulfilling my functions as a SPCN [59]. I find the skills required for a CNS difficult to acruire in the traditional nursing hierarchy [66].

Mishelmovich., et al. [51] describe CNSs as confident in their skills when they are giving significant news or giving reports to patients. Such incidences are numerous in our field. We have to act as specialists in communicating in the clinical environment [22]. In my capacity, I always ensure that I work well in a team $[55,74]$. Such a skill has also been beneficial when I have to lead a group or in meetings [3].

A prerequisite for being a nurse is being clinically competent. We are required to show the ability to thrive in environments where complex decisions must be made concerning patients' lives $[27,55]$. As we deal with patients who are seriously ill, we are highly valued in areas where emotional intelligence is required $[17,73]$. In our expanded capacity, our role requires demonstration of leadership qualities $[53,54]$.

The cases we handle are often complex and do not come as explained in the textbooks. Instead, we have to think critically and apply creative solutions to resolve the needs of our clients. Owing to the demanding work and long hours, we also have to be experts in managing stress and self-care [11]. To be competent in addressing the needs of clients, our ability to administrate, assess, prioritize, and apply problem-solving mechanisms is always called into action [53]. 
Journey of Profound Life Lessons, Learning, Change and Self-awareness: Preparation for a Role Transition from a Senior Saudi Registered Nurse to a Specialist Palliative Care Nurse

Advantages and disadvantages

Our performance especially in the palliative care has several advantages for patients in vulnerable conditions. We are considered as 'fail safes' in detecting symptoms, preventing injuries, and dealing with iatrogenic events before they become complaints, hence saving hospitals from negative publicity $[34,42]$; more importantly, saving patients lives. Our advanced education and experience place us in a position to advice patients, doctors, nurses, and families on the best route of care to follow $[35,40]$. The salient benefit of our role is facilitating change and innovation [43].

Some of the disadvantages include an acute lack of commitment of other staff members. There is a tendency of staff members abdicating their responsibilities and passing their work to the specialist nurses [35]. It has also been suggested that development of specialized nurses deskills generalist nurses [35].

\section{Results}

My search of the electronic databases yielded many results, however, table 2 presents the final number included after applying the IEC. For the type of methods used in each paper please see (The summary table 1).

Table 2: Inclusion search results.

\begin{tabular}{|l|c|c|c|c|c|c|}
\hline$\#$ & $\begin{array}{c}\text { Google } \\
\text { Scholar }\end{array}$ & CINHAL & PubMed & Scopus & $\begin{array}{c}\text { R. } \\
\text { List }\end{array}$ & P.co \\
\hline Included & 29 & 10 & 5 & 2 & 8 & 1 \\
\hline
\end{tabular}

P.co: Personal Communication; R: References.

Most of the papers are qualitative research while only one quantitative research and two used mixed method, which is considered the best method. Literature reviews gave broader idea about the topic and case studies although not generalizable; it can be beneficial in shedding some light on our cases while we compare them to others [36].

\section{My identified skills and how I develop them}

Doing the VIA survey (120 questions) two times on 8/31 and write as $11 / 26$ (2015) illuminated the strong characters as well as the lesser ones. Examples of the test questions can be seen in (figure 6). I do felt that my leadership skill is better than it was first appeared when I did it quickly, not concentrating. However, my strong characters are as expected (Figure 7). The second results are all more like me. I have been told that I was born to be a leader many times, so my 'curiosity' led me to investigate this more while trying to escape my 'cocoon'. Surprisingly, although I used to be an effective member of any team, teamwork result was in the middle in both attempts. This might be true sometimes due to the difficulty of this skill, and being an introvert, so I am working on it. Not sur- prisingly, as Saujani [62] advocates, "Teach girls bravery, not perfection"; I am not brave in contrast to what others say, but this is no longer the case. Social intelligence and judgment are important skills for SPCNs, as mentioned before, also humility for leaders as it is an important transition stage in re-understanding [19]. I am blessed they are my signature characters. I reflect more on the rest in my reflection paper.

The Leadership behavior matrix tool results specified my leadership style (Team leadership $(6,6$ to 9,9), as in figure 8 and that I am strong on both tasks and people leadership skills similarly as the VIA survey. It is a surprising result to me even though felt good at it sometimes. Attempting to profile our-selves, although beneficial to identify those areas that need to be a 'personal action' items for more development, other factors need to be considered (e.g. others and our own perception).

My identified skills for development, during this practicum are:

- $\quad$ Leadership

- $\quad$ Time-management

- $\quad$ Decision-making

- $\quad$ Teamwork

- $\quad$ Research

- $\quad$ Self-care and stress management.

- Reflection and reflective practice (in all forms).

Doing my practicum, this paper and my clinical placement were the main means through which I started the process of identification and development. More discussion about the identification process and reflection on my development is in my reflection paper. I do also draw an extracts from my reflective journal in my reflection paper.

I used different means and resources to develop my skills as to my intention to gain diverse knowledge and expertise while drawing from different disciplines and specialties to gain more understanding. The following are some:

- I enrolled in the student leadership program at Flinders University for the duration of 2015. Many workshops attended and coursework activities done during this time.

- $\quad$ Participated in the skill development certificate, attended several 'degree Plus' workshops (time management, work planning/project management, critical and innovative thinking for the work place, professional mentoring, self-assessment), webinars (Emotional Intelligence, solving the getting experience without experience paradox), and research seminars at Finders University (2015-16). 
Journey of Profound Life Lessons, Learning, Change and Self-awareness: Preparation for a Role Transition from a Senior Saudi Registered Nurse to a Specialist Palliative Care Nurse

- $\quad$ Completed 2 online courses (Work Smarter, Not Harder/Time Management for Personal and Professional Productivity, Effective Problem-Solving and Decision-Making) from 'Coursera' website.
- Keep ongoing personal and professional reflective journal and read literature and resources.

- Follow researcher on twitter and learn from them

- $\quad$ Read other online blogs.

1) Being able to come up with new and different ideas is one of my strong points.

$\square$ very Much Like me $\square$ Like Me $\square$ Neutral $\square$ unlike Me $\square$ very Much Unlike Me

2) I have taken frequent stands in the face of strong opposition.

$\square$ very Much Like Me $\square$ Like Me $\square$ Neutral $\square$ unlike Me $\square$ very Much Unlike Me

3) I never quit a task before it is done.

$\square$ very Much Like Me $\square$ Like Me $\square$ Neutral $\square$ unlike Me $\square$ very Much Unlike Me

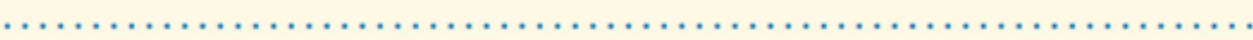

4) I always keep my promises.

$\square$ very Much Like Me $\square$ Like Me $\square$ Neutral $\square$ Unlike Me $\square$ very Much Unlike Me

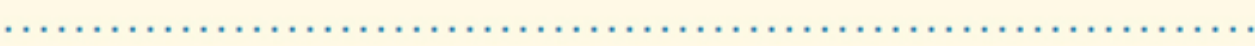

5) I have no trouble eating healthy foods.

$\square$ very Much Like Me $\square$ Like Me $\square$ Neutral $\square$ unlike Me $\square$ very Much Unlike Me

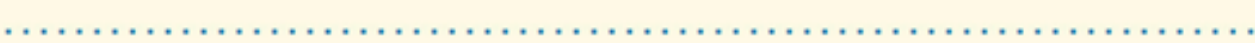

6) I always look on the bright side.

$\square$ very Much Like Me $\square$ Like Me $\square$ Neutral $\square$ Unlike Me $\square$ very Much Unlike Me

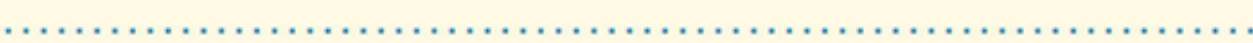

7) I am a spiritual person.

$\square$ very Much Like Me $\square$ Like Me $\square$ Neutral $\square$ unlike Me $\square$ very Much Unlike Me

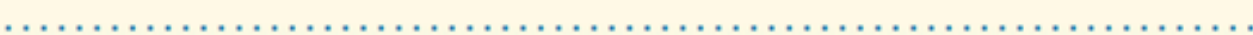

8\} I know how to handle myself in different social situations.

$\square$ very Much Like Me $\square$ Like Me $\square$ Neutral $\square$ unlike Me $\square$ very Much Unlike Me

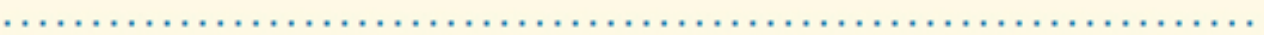

9) I always finish what I start.

$\square$ very Much Like Me $\square$ Like Me $\square$ Neutral $\square$ unlike Me $\square$ very Much Unlike Me

10\} I really enjoy doing small favors for friends.

$\square$ very Much Like Me $\square$ Like Me $\square$ Neutral $\square$ unlike Me $\square$ very Much Unlike Me

11\} There are people in my life who care as much about my feelings and well-being as they do about their own.

$\square$ very Much Like Me $\square$ Like Me $\square$ Neutral $\square$ unlike Me $\square$ very Much Unlike Me

12\} As a leader, I treat everyone equally well regardless of his or her experience.

$\square$ very Much Like Me $\square$ Like Me $\square$ Neutral $\square$ unlike Me $\square$ very Much Unlike Me

Figure 6: Screen shot, VIA survey.

Citation: Fatimah Alabduljabbar. "Journey of Profound Life Lessons, Learning, Change and Self-awareness: Preparation for a Role Transition from a Senior Saudi Registered Nurse to a Specialist Palliative Care Nurse". Acta Scientific Medical Sciences 4.11 (2020): 112-137. 


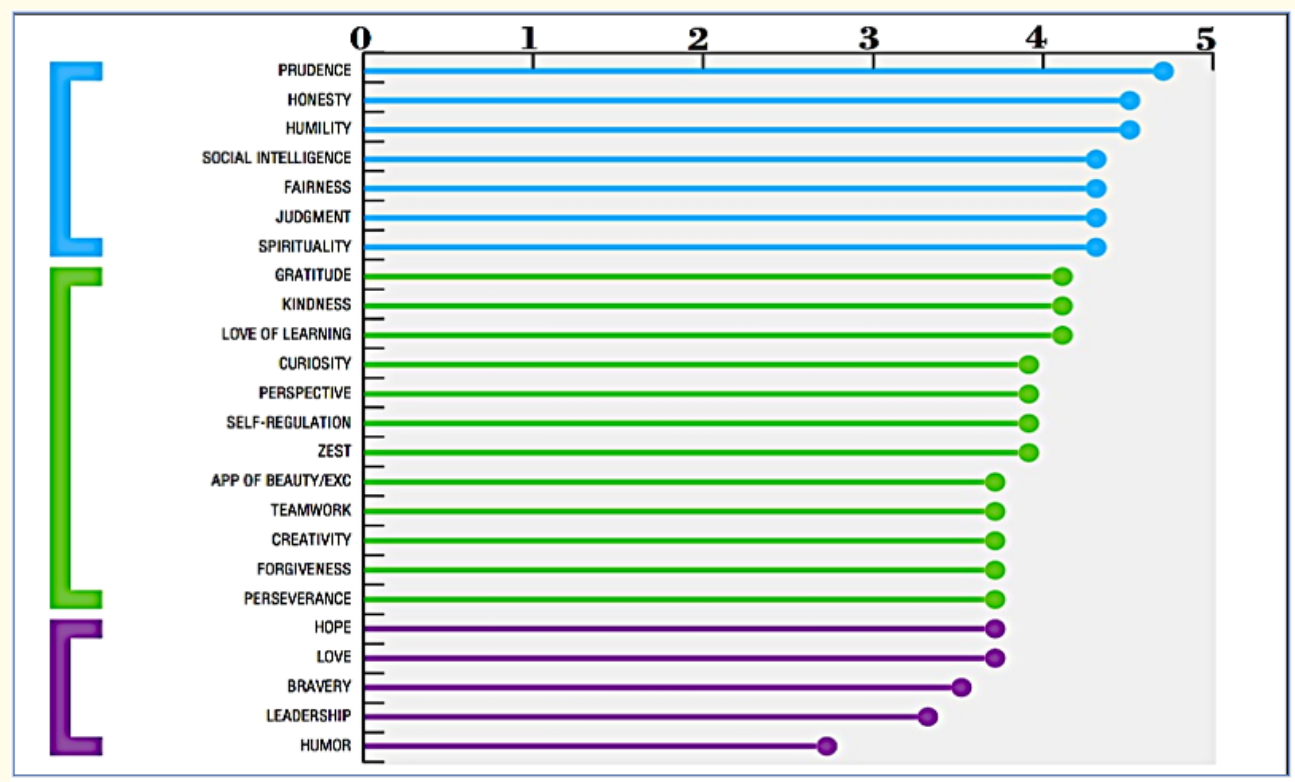

Figure 7: Via survey results, $1^{\text {st }}$ attempt.



Figure 8: LBM results, team leadership.

\section{Discussion}

My analysis of the literature review shows that though the role of the SN has been discussed in literature for over 90 years, it has not been fully embraced within the caregiving setting. A major concern for me has been lack of a clear role for the CNSs. Like "Alice in Wonderland", I was wondering all the time, but not lost. While thinking of those SPCNs that I observed, I feel like they are performing other health professionals' jobs sometimes.

My practicum positively correlates with the literature review on the issue of transition. Coming from SA, preparing for specialist role, I initially had to depend on the knowledge I had acquired in my practice as an SRN and build on it. The transition was not simply gaining knowledge about the roles, instead, understanding those patients/families who are in transitions too. This is greatly influencing the nursing care provided. Further, it involves understanding a new culture.

In future, there are several recommendations that should be applied. First, hospitals in SA should be attached to educational institutions where nurses can study specialized nursing education. The SA curricula are deficient in terms of giving nursing students the knowledge they require in order to transit to CNS. The course should also be designed in a way that it impacts the skills of transition on the nurses which would make the process easier and increase the success rate of nurses who transition [66].

Considering my transition journey, I know that there are limited palliative nurses in SA to assist in the curricula development process. While I have enjoyed learning in Australia owing to the teaching capacity, the same is not true for SA. Further, this will be faced by poor funding of the program. The same limitation will face the issue of attaching educational institutions to hospitals to encourage collaboration.

\section{Conclusion}

The benefits that the nursing profession has accrued from specialized nurses have been adequately addressed. With their advanced experience and knowledge, the CNSs play a complementary role to that of physicians and generalist nurses. Through my practicum and the literature review, there are a lot of grey areas concerning the SRN transitioning to a SPCN. Already, the role of SRNs is not adequately addressed in most situations. As a result, transitioning to SPCN only compounds the issue. The paper has also pointed to the inadequacy of educational facilities to train SN especially in developing nations. For successful transition to SPCN, there needs to be an increase in the number of educational facilities that integrates the specialized curricula. My experience as provided in this paper should act as a way of providing direction to SRNs who wish to explore new opportunities abroad, be proactive and strive to develop professionally as well as personally. Further, it should be a guide for policy makers to identify areas in nursing that can benefit through this research to ensure that SA benefits as much as other countries from the benefits accrued from CNS.

\section{Acknowledgements}

I am so thankful to my God whose love, grace and blessings; care, kindness, and presence are filling my hart and life. Without God's miracles, I would not be able to do this practicum and navigates my way in this life. 
Secondly, I do not know how to thank my supervisor Deb Rawling for every thing she did to support me throughout my journey. She was beside me when I need her all the time. I would like to thank her especially for planting the seed for this practicum, meaning by suggesting me to look at something related to my new role. Thank you also, for your teaching, listening, advice and support and more importantly, your great patience and faith in me despite the hard times.

I would like to extend my appreciations to my palliative course coordinator Ms. Kim Devery, and Dr. Sam Davis, the applied Gerontology course coordinator, for all their support, listening, sharing of my tears and smiles, and more importantly for their patience and allowing me for time to understand my life. I especially thank Dr. Sam for sharing with me the "Leadership Behavior Matrix" that I use in this practicum.

I cannot forget also Dr. Aileen Collier; I do appreciate much your insight and all the lessons that you teach me in this life. Also for encouraging your students and suggesting us to follow researchers on twitter to learn from them and the conferences. Reading your thesis was a blessing to me.

I deeply appreciate and thank Dr. Leeroy Williams for his wisdom, discussion, encouraging for reflective practice and his transportation to me from/to the pain clinic placement. Thank you for sharing my pain, smile and all your support. Also to Dr. Peter Poon and Michael Franco for their orientation, teaching and ensuring extending their support to what would happen next and all the time.

I extend my appreciation to the palliative care consultants, specialist nurses, patient/families who I learnt from their wisdom as well as all the health professionals who shared their space, time, knowledge and experience with me during my clinical placement.

My organization without your funding and continuous support, the clinical placement would not be possible.

My family you are in the heart. Thank you for everything. I love you all. Please forgive me for any bothering I might caused.

Appendix 1:

\section{Flinders The Flinders University Skill Development Certificate}

\section{Confirmation of Work Experience}

Please describe your work experience; the tasks or projects you undertook, the skills you have developed through this experience and the period of time you were at this placement.

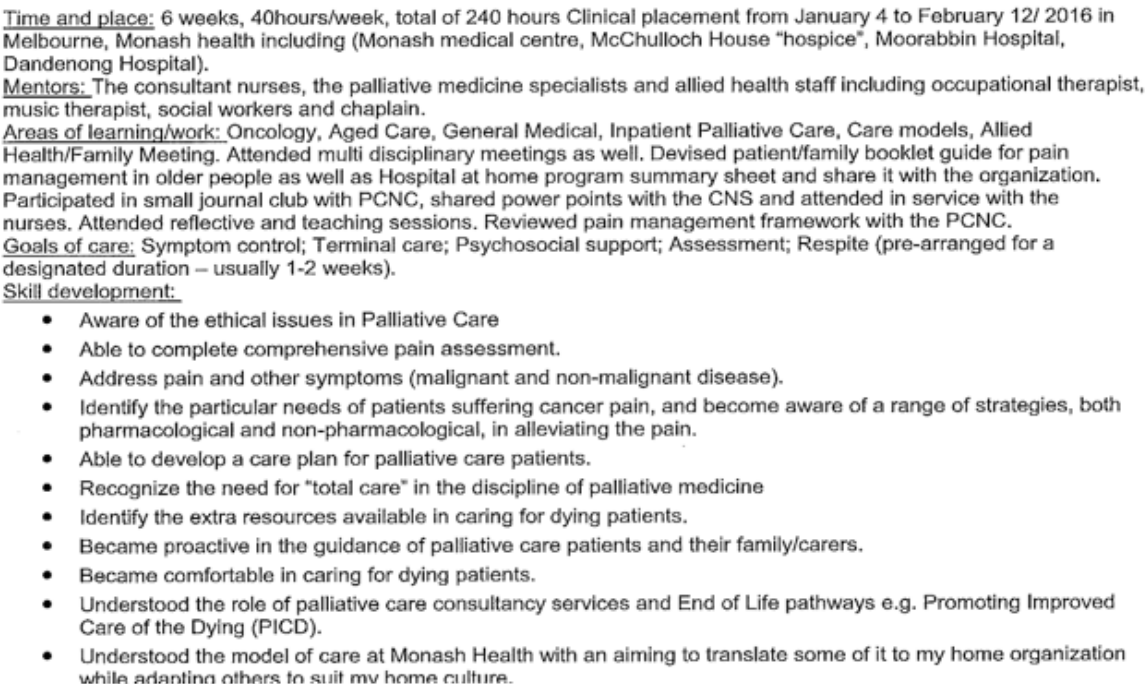

Please have the next section completed by someone who can verify your engagement in at least 80 hours of work experience.

Thank you for completing this form. This is to agree that the student has been successfully engaged in work experience with your organisation, and has completed:

$80+$ hours of work experience

V120+ hours of work experience

\begin{tabular}{|l|l}
\hline Student Name: & Fatimah Saeed Al AbdulJabbar. \\
\hline Organisation: & Monash Health. \\
\hline $\begin{array}{l}\text { Confirmed: } \\
\text { (Please sign) }\end{array}$ & Tw W Cina \\
\hline Name: & Dr. Leeroy Wiliam. \\
\hline Role: & $\begin{array}{l}\text { Palliative Medicine Specialist, Adjunct Senior Lecturer } \\
\text { Monash Health | Eastern Health | Monash University }\end{array}$ \\
\hline Date: & 27/ June/ 2016 \\
\hline
\end{tabular}


Journey of Profound Life Lessons, Learning, Change and Self-awareness: Preparation for a Role Transition from a Senior Saudi Registered Nurse to a Specialist Palliative Care Nurse

\section{Bibliography}

1. Alligood MR. "Nursing theorists and their work". Elsevier Health Sciences (2013).

2. Anderson J K. "The work-role transition of expert clinician to novice academic educator". Journal of Nursing Education 48 (2009): 203-208.

3. Becker E., et al. "Clinical nurse specialists shaping policies and procedures via an evidence-based clinical practice council". Clinical Nurse Specialist: The Journal for Advanced Nursing Practice 26.2 (2012): 74-86.

4. Blanchard K. "The seven Dynamics of change". The Inside Guide, Commentary on each of the principles was written by the Editor of The Public Sector Manager (1992).

5. Bousfield C. "A phenomenological investigation into the role of the clinical nurse specialist". Journal of Advances in Nursing 25 (1997): 245-256.

6. Brennan $\mathrm{G}$ and McSherry R. "Exploring the transition and professional socialisation from health care assistant to student nurse". Nurse Education in Practice 7.4 (2007): 206-214.

7. Brinkert R. "A literature review of conflict communication causes, costs, benefits and interventions in nursing". Journal of Nursing Management 18.2 (2010): 145-156.

8. Bulman C and Schutz S. "Reflective practice in nursing". John Wiley and Sons (2013).

9. Carryer J., et al. "The core role of the nurse practitioner: practice, professionalism and clinical leadership". Journal of Clinical Nursing 16.10 (2007): 1818-1825.

10. CASP. Appraising the evidence, viewed on $10 / 0 \mathrm{ct} / 2014$ (2013).

11. Chick, K., et al. "Enhancing patient education through clinical nurse specialist collaboration". Clinical Nurse Specialist: The Journal for Advanced Nursing Practice 26.6 (2012): 317-322.

12. Clark JE., et al. "Training oncology and palliative care clinical nurse specialists in psychological skills: Evaluation of a pilot study". Palliative and Supportive Care 13.03 (2015): 537-542.

13. Cragg CB and Andrusyszyn MA. "The process of master's education in nursing: evolution or revolution?". International Journal of Nursing Education Scholarship 2.1 (2005).

14. Critical Appraisal Skills Programme, CASP, UK (2013).

15. Custer D. "Autoethnography as a transformative research method". The Qualitative Report 19.37 (2014): 1-13.

16. Current Nursing. "Nursing Theories, a companion to Nursing Theories and Models" (2012).
17. Curtis., et al. "Developing leadership in nursing: exploring core factors”. British Journal of Nursing 20.5 (2015): 306.

18. Daveson BA., et al. "The effectiveness and cost-effectiveness of inpatient specialist palliative care in acute hospitals for adults with advanced illness and their caregivers". The Cochrane $\mathrm{Li}$ brary (2015).

19. Dunleavy P. "Becoming more creative in academic work" (2015).

20. Ewing G., et al. "Delivering palliative care in an acute hospital setting: views of referrers and specialist providers". Journal of Pain and Symptom Management 38.3 (2009): 327-340.

21. Felemban E., et al. "Cultural view of Nursing in Saudi Arabia". Middle East Journal of Nursing 8.4 (2014): 8-14.

22. Fisher K. "Specialist palliative care for patients with non-cancer diagnosis". Nursing Standard 21.4 (2006): 44.

23. Foster J and Flanders S. "Challenges in Clinical Nurse Specialist Education and Practice". Online Journal of Issues in Nursing 19.2 (2014): 32 .

24. Fulton JS., et al. "Foundations of clinical nurse specialist practice". Springer Publishing Company (2014).

25. Gardner G., et al. "Making nursing work: breaking through the role confusion of advanced practice nursing". Journal of Advanced Nursing 57.4 (2007): 382-391.

26. Gerrish K., et al. "The role of advanced practice nurses in knowledge brokering as a means of promoting evidencebased practice among clinical nurses". Journal of Advanced Nursing 67.9 (2011): 2004-2014.

27. Glen $S$ and Waddington K. "Role transition from staff nurse to clinical nurse specialist: a case study". Journal of Clinical Nursing 7.3 (1998): 283-290.

28. Goodman J., et al. "Counseling adults in transition: Linking practice with theory". ( $3^{\text {rd }}$ edition). Springer Publishing Co (2006).

29. Gott M and Ingleton C. "Living with ageing and dying: palliative and end of life care for older people". Oxford University Press (2011).

30. Heitkemper MM and Bond EF. "Clinical nurse specialists: state of the profession and challenges ahead". Clinical Nurse Specialist. 18.3 (2004): 135-140.

31. Hibbert D., et al. "Perspectives on Specialist Nursing in Saudi Arabia: A National Model for Success". Annuals of Saudi Medicine 32.1 (2015): 78-85. 
32. Hodgins M and Boydell KM. "Interrogating ourselves: Reflections on arts-based health research'. Forum Qualitative Sozialforschung/Forum: Qualitative Social Research 15.1 (2014): 10.

33. International Council of Nursing (2013).

34. Jack B., et al. "Hospital based palliative care teams improve the symptoms of cancer patients". Palliative Medicine 17.6 (2003): 498-502.

35. Jack B., et al. "Do hospital-based palliative care clinical nurse specialists de-skill general staff?". International Journal of Palliative Nursing 8.7 (2002): 336-340.

36. Kara Helen. "Research and Evaluation for Busy Practitioners: A time saving guide". The Policy Press, Bristol UK (2012).

37. Kearney M., et al. "Self-care of physicians caring for patients at the end of life". JAMA 301.11 (2009): 1155-1164.

38. Kearney M and Weininger R. "Learning to Breathe Underwater: Towards a Self-Awareness Based Model of Self Care". video, The Buddhist Contemplative Care Symposium, the New York Zen Center for Contemplative Care and the Garrison Institute (2012).

39. Kleinpell, R., et al. "Addressing issues impacting advanced nursing practice worldwide". Online Journal of Issues in Nursing 19.1 (2014).

40. Lang SV. "The Vision, Value, and Voice of the Clinical Nurse Specialist: Implementing a Palliative Care Program". Clinical Nurse Specialist 23.4 (2009) 226.

41. Lazarus RS and Folkman S. "Stress Appraisal and Coping $1^{\text {st }}$ Edition". Springer, New York (1984).

42. Leary A., et al. "Dimensions of clinical nurse specialist work in the UK". Nursing Standard 23.15 (2008): 40-44.

43. Lewandowski W and Adamle K. "Substantive areas of clinical nurse specialist practice: A comprehensive review of the literature". Clinical Nurse Specialist 23.2 (2009): 73-90.

44. Lewis Caroll. Alice in Wonder Land, Book Virtual, UK (1865).

45. Lugton J and McIntyre R. "Palliative care: The nursing role". Elsevier Health Science (2005).

46. Malhotra P. "An autoethnographic journey of intercountry adoption". The Qualitative Report 18.63 (2013): 1-13.

47. Manning L and Neville S. "Work-role transition: from staff nurse to clinical nurse educator". Nursing Praxis in New Zealand 25.2 (2009): 41-54.
48. McCourt R., et al. "General nurses' experiences of end-of-life care in the acute hospital setting: a literature review". International Journal of Palliative Nursing 19.10 (2013).

49. Meleis AI., et al. "Experiencing transitions: an emerging middle-range theory". Advances in Nursing Science 23.1 (2000): 12-28.

50. Miner DC. "Self-in-Relation Theory and the Role of the Clinical Nurse Specialist Part I: Theory and Role Development". Clinical Nurse Specialist 9.5 (1995): 280.

51. Mishelmovich N., et al. "Breaking significant news: The experience of clinical nurse specialists in cancer and palliative care". European Journal of Oncology Nursing (2015).

52. Monroe B and Speck P. "Team effectiveness". Teamwork in palliative care: fulfilling or frustrating (2006): 201-210.

53. Montgomery L and Steinke E. "The clinical nurse specialist in the acute care setting". Kansas Nurse 81.5 (2006): 1-2.

54. Muller A., et al. "Evidence-based practice implementation strategy: the central role of the clinical nurse specialist". Nursing Administration Quarterly 35.2 (2011): 140-151.

55. Newton J and McVicar A. "Evaluation of the currency of the Davies and Oberle (1990) model of supportive care in specialist and specialised palliative care settings in England". Journal of Clinical Nursing 23.11-12 (2018): 1662-1676.

56. O'Connor., et al. "Palliative care nurse consultants in Melbourne: a snapshot of their clinical role". International Journal of Palliative Nursing 14.7 (2008).

57. O'Connor M and Chapman Y. "The palliative care clinical nurse consultant: an essential link". Collegian 15.4 (2008): 151-157.

58. Oddsdóttir, EJ and Sveinsdóttir H. "The content of the work of clinical nurse specialists described by use of daily activity diaries". Journal of Clinical Nursing 20.9-10 (2011): 1393-1404.

59. Pooler J and Plimley K. "Transition: from staff nurse to clinical nurse specialist". Cancer Nursing Practice 3.2 (2004): 23-27.

60. Raab D. "Transpersonal approaches to autoethnographic research and writing". The Qualitative Report 18.42 (2013): 1-19.

61. Rosser M., et al. "Evaluation of a mentorship programme for specialist practitioners". Nurse Education Today 24.8 (2004): 596-604.

62. Saujani R. "Teach girls bravery, not perfection”. (2016).

63. Schlossberg NK. "Counseling adults in transition: Linking practice with theory". Springer Publishing Company (2005). 
64. Skilbeck J., et al. "Clinical nurse specialists in palliative care. Part 1. A description of the Macmillan Nurse caseload". Palliative Medicine 16.4 (2002): 285-296.

65. Skilbeck J and Payne S. "Emotional support and the role of clinical nurse specialists in palliative care". Journal of Advanced Nursing 43.5 (2003): 521-30.

66. Spoelstra SL and Robbins LB. "A qualitative study of role transition from RN to APN". International Journal of Nursing Education Scholarship 7.1 (2010).

67. Spross J A and Lawson M T. "Conceptualizations of advanced practice nursing”. In AB Hamric and J Spross (Eds.), The clinical nurse specialist in theory and practice ( $2^{\text {nd }}$ edition $)$. Philadelphia: W. B. Saunders (2009): 33-74.

68. Stilos $\mathrm{K}$ and Daines P. "Exploring the leadership role of the clinical nurse specialist on an inpatient palliative care consulting team". Nursing Leadership 26.1 (2013): 70-78.

69. Taylor R and Chadwick S. "Palliative care in hospital: Why is it so difficult?”. Palliative Medicine 29.9 (2015): 770-773.

70. Teno JM and Connor SR. "Referring a patient and family to high-quality palliative care at the close of life: "We met a new personality... with this level of compassion and empathy". JAMA 301.6 (2009): 651-659.

71. The Saudi Commission for Health Specialties (2013).

72. The VIA Institute on Character. The VIA Survey (2016).

73. Thompson CJ and Nelson-Marten P. "Clinical nurse specialist education: actualizing the systems leadership competency". Clinical Nurse Specialist 25.3 (2011): 133-139.

74. Tim Harford. How frustration can make us more creative (2016).

75. Tringali CA., et al. "Clinical nurse specialist practice in a care coordination model". Clinical Nurse Specialist: The Journal for Advanced Nursing Practice 22.5 (2008): 231-239.

76. Warnock C., et al. "Breaking bad news in inpatient clinical settings: role of the nurse". Journal of Advanced Nursing 66.7 (2010): 1543-1555.

77. Willis EM. "The problem of time in ethnographic health care research". Qualitative Health Research 20.4 (2010): 556-564.

\section{Assets from publication with us}

- Prompt Acknowledgement after receiving the article

- Thorough Double blinded peer review

- Rapid Publication

- Issue of Publication Certificate

- High visibility of your Published work

Website: www.actascientific.com/

Submit Article: www.actascientific.com/submission.php Email us: editor@actascientific.com

Contact us: +919182824667

78. WU V. Quiet Revolution (2016). 